Resultaten van 10 jaar daarmoetikzijn voor de provincie Zuid-Holland 



\section{Resultaten van 10 jaar daarmoetikzijn voor de provincie Zuid-Holland}

C.M. Goossen

Dit onderzoek is uitgevoerd door Wageningen Environmental Research (Alterra) in opdracht van en gefinancierd door de provincie Zuid-Holland (projectnummer 5200042559-667-2016-9).

Wageningen Environmental Research

Wageningen, januari 2017

Rapport 2781

ISSN 1566-7197 
Goossen, C.M., 2017. Resultaten van 10 jaar daarmoetikzijn voor de provincie Zuid-Holland.

Wageningen, Wageningen Environmental Research, Rapport 2781. 28 blz.; 12 fig.; 12 tab.; 3 ref.

Op basis van 8.935 bezoekers van de websites www.daarmoetikzijn.nl en myplacetobe.eu uit de provincie Zuid-Holland is een analyse gemaakt naar de aantrekkelijkheid van het landschap. Het gemiddelde rapportcijfer van het landschap in Zuid-Holland is de afgelopen tien jaar een zes en de laatste jaren dalend. Vooral bebouwing draagt negatief bij aan het rapportcijfer, maar ook bedrijventerreinen, industriegebieden en geluid van auto's, treinen, vliegverkeer en bossen. Heide-, zand- en duingebieden leveren daarentegen een positieve bijdrage aan het rapportcijfer, evenals hoogteverschillen. Deze zes, van de vijftien, gebruikte indicatoren verklaren voor 8 procent het rapportcijfer. Circa een derde van de bezoekers (32 procent) uit Zuid-Holland geeft een onvoldoende aan het landschap rond de eigen woonplaats. Ruimtelijk gezien krijgt echter het grootste deel van het landschap in Zuid-Holland een voldoende. Bos is het meest gewilde landschapstype. Twee derde van de bezoekers wil bezienswaardigheden hebben in het ideale landschap en geluidbelasting, horizonvervuiling en drukte door recreatieve fietsers worden als storend ervaren.

Trefwoorden: landschap, Zuid-Holland, aantrekkelijkheid, indicatoren

Dit rapport is gratis te downloaden van http://dx.doi.org/10.18174/402840 of op www.wur.nl/environmental-research (ga naar 'Wageningen Environmental Research' in de grijze balk onderaan). Wageningen Environmental Research verstrekt geen gedrukte exemplaren van rapporten.

2017 Wageningen Environmental Research (instituut binnen de rechtspersoon Stichting Wageningen Research), Postbus 47, 6700 AA Wageningen, T 03174807 00, E info.alterra@wur.nl, www.wur.nl/environmental-research. Wageningen Environmental Research is onderdeel van Wageningen University \& Research.

- Overname, verveelvoudiging of openbaarmaking van deze uitgave is toegestaan mits met duidelijke bronvermelding.

- Overname, verveelvoudiging of openbaarmaking is niet toegestaan voor commerciële doeleinden en/of geldelijk gewin.

- Overname, verveelvoudiging of openbaarmaking is niet toegestaan voor die gedeelten van deze uitgave waarvan duidelijk is dat de auteursrechten liggen bij derden en/of zijn voorbehouden.

Wageningen Environmental Research aanvaardt geen aansprakelijkheid voor eventuele schade voortvloeiend uit het gebruik van de resultaten van dit onderzoek of de toepassing van de adviezen. 


\section{Inhoud}

$\begin{array}{ll}\text { Samenvatting } & 5\end{array}$

1

Inleiding $\quad 7$

$\begin{array}{lll}1.1 & \text { Aanleiding } & 7\end{array}$

$\begin{array}{lll}1.2 & \text { Doel van het onderzoek } & 7\end{array}$

$\begin{array}{lll}1.3 & \text { Probleemstelling en onderzoeksvragen } & 7\end{array}$

1.4 Opzet van de website $\quad 8$

$\begin{array}{lll}1.5 & \text { Werkwijze } & 9\end{array}$

2

$\begin{array}{lr}\text { De bezoekers } & 10\end{array}$

$\begin{array}{lll}2.1 & \text { Bezoek van de afgelopen tien jaar } & 10\end{array}$

$\begin{array}{ll}2.2 & \text { Persoonlijke kenmerken } \\ 2.3 & 10\end{array}$

$\begin{array}{lll}2.3 & \text { Representativiteit } & 12\end{array}$

3

$\begin{array}{ll}\text { De Resultaten } & 13\end{array}$

3.1 Aantrekkelijkheid $\quad 13$

$\begin{array}{ll}3.2 & \text { Verklaringen aantrekkelijkheid } \\ 3.3 & 15\end{array}$

$\begin{array}{lll}3.3 & \text { Relatie werkelijk en gewenst aanbod } & 16\end{array}$

$\begin{array}{llr}4 & \text { Voorkeuren } & 18\end{array}$

$\begin{array}{lll}4.1 & \text { Inleiding } & 18\end{array}$

$\begin{array}{lll}4.2 & \text { Het ideale landschap } & 18\end{array}$

$\begin{array}{lll}4.3 & \text { Voorkeuren door de jaren heen } & 20\end{array}$

$5 \quad$ Conclusies en aanbevelingen $\quad 24$

$\begin{array}{lll}5.1 & \text { Conclusies } & 24\end{array}$

5.2 Aanbevelingen 25

$\begin{array}{ll}\text { Literatuur } & \mathbf{2 7}\end{array}$ 



\section{Samenvatting}

De provincie Zuid-Holland wil graag de mening van haar inwoners weten betreffende de aantrekkelijkheid van het landschap. Gevraagd wordt of er de afgelopen 10 jaar een verandering geweest is in de opvatting van burgers uit Zuid-Holland over de aantrekkelijkheid van het landschap in hun directe woonomgeving. Deze vraag kan beantwoord worden door gebruik te maken van de data afkomstig uit de websites www.daarmoetikzijn.nl en www.myplacetobe.eu. Op deze websites wordt een algemene vraag gesteld over de aantrekkelijkheid van het landschap in de eigen woonomgeving. In Zuid-Holland hebben in de afgelopen tien jaar 8.935 unieke bezoekers deze websites bezocht. Gemiddeld is van de bezoekers $60 \%$ een man en is de gemiddelde leeftijd over die tien jaar 44 jaar. Er blijkt een sterke oververtegenwoordiging te zijn van de leeftijdsklasse 40 tot en met 65 jaar. Jongeren en ouderen zijn minder vertegenwoordigd. Er is een significant verschil tussen de aantrekkelijkheidsscore van het landschap en geslacht en leeftijd gevonden. Vrouwen vinden het landschap in hun directe woonomgeving aantrekkelijker dan mannen. Ook naarmate men ouder wordt, stijgt de score voor de aantrekkelijkheid. De ruimtelijke verdeling van de bezoekers is wel in overeenstemming met de daadwerkelijke verdeling.

De gemiddelde aantrekkelijkheid van het landschap rond hun eigen woonplaats over de afgelopen tien jaar is een 6,1 , gebaseerd op de scores uit daarmoetikzijn en myplacetobe; een gemiddelde dat lager ligt dan in de rest van Nederland, dat een 6,9 scoort. Bovendien neemt het gemiddelde de laatste jaren af, met zelfs gemiddeld een onvoldoende vanaf 2011.

Verantwoordelijk hiervoor lijken die landschapskenmerken te zijn die vooral een negatieve bijdrage leveren aan dat rapportcijfer. Vooral bebouwing drukt negatief op het rapportcijfer, maar ook bedrijventerreinen en industriegebieden en geluid van auto's, treinen en vliegverkeer, maar ook bossen. Heide-, zand- en duingebieden leveren daarentegen een positieve bijdrage aan het rapportcijfer, evenals hoogteverschillen. Wel moet worden opgemerkt dat zes van de vijftien gebruikte indicatoren voor maar $8 \%$ bijdragen aan de verklaring van het rapportcijfer. Er zijn dus ook andere kenmerken die invloed hebben op de aantrekkelijkheidsscore.

Circa een derde van de bezoekers (32\%) uit Zuid-Holland geeft een onvoldoende (lager dan 6) aan het landschap rond de eigen woonplaats. Wanneer naar de ruimtelijke verdeling van gebieden met een onvoldoende voor de aantrekkelijkheid wordt gekeken, blijken deze geconcentreerd in een strook te liggen in gebieden met veel bebouwing, bedrijventerreinen en industriegebieden, horizonvervuiling en geluidbelasting. Deze strook zijn gebieden rond de snelwegen A12, A20, A15 en A16. Dit zijn ook de gebieden waar relatief veel bezoekers wonen. Deze bezoekers hebben dus een stevige invloed op het gemiddelde aantrekkelijkheidscijfer van de hele provincie. Want wanneer naar het grondoppervlak van de gehele provincie wordt gekeken en waar rapportcijfers over bekend zijn, blijkt dat $80 \%$ van het grondoppervlak van de provincie een voldoende krijgt. Ruimtelijk gezien krijgt dus het grootste deel van het landschap in Zuid-Holland een voldoende.

Bezoekers die in een gebied wonen met veel (half)open agrarisch gebied hebben daar ook een voorkeur voor in hun ideale landschap. Dit geldt ook voor heide-, zand- en duingebieden en de zee en grote meren. Opvallend is dat dit ook geldt voor bebouwing, bedrijventerreinen en industriegebieden. Misschien speelt de relatie met werkgelegenheid hier een rol. Hoe meer horizonvervuiling in de woonomgeving van de bezoeker aanwezig is, hoe minder horizonvervuiling hij/zij in het ideale landschap wil zien.

De gemiddelde Zuid-Hollander wil het liefst $31 \%$ bos hebben in zijn/haar ideale landschap. Maar ook de zee en meren moeten aanwezig zijn (circa 21\%). Het ideale landschap moet verder 18\% heide-, zand- of duingebied hebben. Ook sloten, beken, rivieren en plassen en natuurlijk grasland, moeras en riet moeten voor $14 \%$ onderdeel uitmaken van het ideale landschap. De gewenste hoeveelheid halfopen agrarisch gebied is bijna even groot (16\%) als de gewenste hoeveelheid kleinschalig 
agrarisch gebied. Een voorkeur voor open agrarisch gebied (13\%), bebouwing (13\%) en industriegebieden ( $5 \%$ ) scoort gemiddeld laag.

Ruim de helft van de websitebezoekers wil enige mate van reliëf en twee derde wil bezienswaardigheden hebben in het ideale plaatje. $76 \%$ van de website-bezoekers in Zuid-Holland vindt het in enige mate storend om geluid te horen van auto's, treinen en/of vliegtuigen. Ook horizonvervuiling in de vorm van hoogbouw, windturbines en elektriciteitsmasten wordt door $70 \%$ als enige mate van storend ervaren. Drukte van recreatieve fietsers is relatief het minst storend. Iets meer dan de helft ( $57 \%)$ vindt het in enige mate storend.

Opvallend zijn de analyses voor bos. Het is het landschapstype dat de grootste voorkeur heeft onder de Zuid-Hollanders. Die voorkeur neemt echter de afgelopen jaren wel af en bos levert zelfs een negatieve bijdrage aan de aantrekkelijkheidsscore. Hoe meer bos, hoe minder aantrekkelijk en hoe minder bos, hoe aantrekkelijker het landschap wordt gevonden. Het is nog onduidelijk welke rol dit landschapstype heeft. Een vervolgonderzoek naar de rol van bos kan hier misschien duidelijkheid scheppen. Een mogelijkheid is om gebruik te maken van 1.450 emailadressen van Zuid-Hollanders die hebben aangegeven bereid te zijn om mee te doen met vervolgonderzoek.

Opvallend is ook de rol van sloten, beken, rivieren en plassen. In het ideale landschap is dit water gewild, maar dat komt niet tot uiting in de aantrekkelijkheidsscores van Zuid-Holland. Misschien ligt dit aan de visuele verschijning van dit type water. Zuid-Holland beschikt namelijk over relatief veel kaarsrechte sloten die een niet erg natuurlijke uitstraling hebben. Meestal zijn deze sloten gekoppeld aan een open agrarisch gebied dat niet de voorkeur heeft van de Zuid-Hollanders in hun samenstelling van ideale landschap. Ook hier zal nader onderzoek nodig zijn om de rol van dit type water te onderzoeken voor de Zuid-Hollandse situatie.

De provincie Zuid-Holland staat voor een grote opgave om het landschap aantrekkelijk te maken. De energie zal niet zozeer in het ontwikkelen van een bepaald landschapstype gaan zitten, maar meer in het tegengaan van of het verbergen van ontwikkelingen die negatief bijdragen aan de aantrekkelijkheid. De provincie staat voor een grote bouwopgave. Juist bebouwing drukt negatief door op de aantrekkelijkheid. Aan een bouwopgave zou dus ook een groenopgave gekoppeld moeten worden. Waar gebouwd wordt, moet ook groen ontwikkeld worden en dan het liefst in de vorm van bos en natuurlijk grasland. Het "verbergen" van de bedrijventerreinen en industriegebieden met een zeer brede groenzone zou het landschap visueel aantrekkelijker kunnen maken. Dit geldt ook voor de glastuinbouwgebieden en langs snelwegen. Opgaande begroeiing langs de snelwegen levert tevens een positieve bijdrage aan het tegengaan van geluidbelasting en fijnstof. Dwars door bouwlocatie, bedrijventerreinen en industriegebieden zou ook een brede groenzone ontwikkeld kunnen worden om de verbinding met de "oude" woongebieden te waarborgen.

Of een groot bosgebied zoals een behoorlijke uitbreiding van het bestaande Bentwoud gewenst is, is op basis van deze resultaten nog niet te zeggen. Daarvoor zijn de resultaten te tegenstrijdig. Er is een duidelijke voorkeur dat bossen een derde van een landschap van $25 \mathrm{~km}^{2}$ moeten beslaan, maar tegelijkertijd lijkt bos een negatieve bijdrage te leveren aan de aantrekkelijkheid. Nader onderzoek is hierover gewenst. 


\section{$1 \quad$ Inleiding}

\section{$1.1 \quad$ Aanleiding}

Tien jaar is de website www.daarmoetikzijn.nl in de lucht en wordt nog steeds veel bezocht. Tot eind 2015 hebben veel inwoners van Zuid-Holland de website bezocht om hun ideale plekje in Nederland te vinden. Nederland kent vele mooie plekjes, maar niet iedereen weet waar ze liggen. En soms komen de door anderen aangewezen mooie plekjes niet overeen met wat een individu wil. Een toerist moet eigenlijk eerst weten dat een bepaalde regio voor hem/haar mooi zou kunnen zijn en kan dan die regio-informatie opvragen. De website www.daarmoetikzijn.nl keert het om door eerst te vragen wat een toerist aantrekkelijke kenmerken van een landschap vindt. Op de website kan men zijn/haar ideale landschap samenstellen. Er wordt letterlijk gevraagd: "Wat is voor u het ideale landschap voor de recreatie activiteiten die $u$ wilt ondernemen? In drie stappen weet $u$ waar in Nederland een aantrekkelijk landschap op u ligt te wachten. Maak uw keuze, vind en ontdek het gebied waar u moet zijn! Misschien is dat wel een plek waar u nooit aan had gedacht." Aan het eind krijgt de bezoeker een persoonlijke kaart waarop staat aangegeven in hoeverre gebieden al dan niet overeenkomen met de voorkeuren. Ook wordt gevraagd een rapportcijfer te geven over de aantrekkelijkheid van het landschap van zijn/haar eigen woonomgeving.

Dit levert interessante data op betreffende meningen over het eigen landschap en de voorkeuren voor bepaalde landschapstypen van de bezoekers. Deze meningen en voorkeuren worden door Wageningen Environmental Research opgeslagen in het E-scape-bestand. De provincie Zuid-Holland heeft gevraagd om enkele analyses te maken over de afgelopen tien jaar van dit bestand voor Zuid-Holland.

\subsection{Doel van het onderzoek}

De provincie Zuid-Holland wil graag de mening van haar inwoners weten betreffende de aantrekkelijkheid van het landschap. Zelf doet de provincie regelmatig onderzoek onder burgers naar de tevredenheid met het groen in de directe woonomgeving. Het is minder bekend in hoeverre de burgers het landschap in hun directe woonomgeving aantrekkelijk vinden.

\subsection{Probleemstelling en onderzoeksvragen}

De probleemstelling van dit onderzoek luidt:

Is er de afgelopen tien jaar een verandering geweest in de opvatting van burgers uit Zuid-Holland over de aantrekkelijkheid van het landschap in hun directe woonomgeving?

De onderzoeksvragen die aan deze probleemstelling zijn gekoppeld, luiden:

- Wat is het gemiddelde rapportcijfer dat Zuid-Hollandse burgers geven aan de aantrekkelijkheid van het landschap in hun directe woonomgeving?

- Is dat rapportcijfer veranderd in de afgelopen tien jaar?

- Welke verklaringen zijn daarvoor te geven?

- Welke type landschap wordt als aantrekkelijk ervaren? Welke kenmerken zijn bepalend?

- Zijn de verschillen in aantrekkelijkheid afhankelijk van waar men woont?

- Is er een verschil in opvatting voor het type landschap wat men heeft en wat men wenst?

Deze onderzoeksvragen zijn met behulp van het E-scape-bestand te beantwoorden voor Zuid-Holland. 


\subsection{Opzet van de website}

De website www.daarmoetikzijn.nl ziet er schematisch uit als in onderstaande figuur. Buiten de eigenlijke site (dikke kader) vallen de database en het GIS-model.

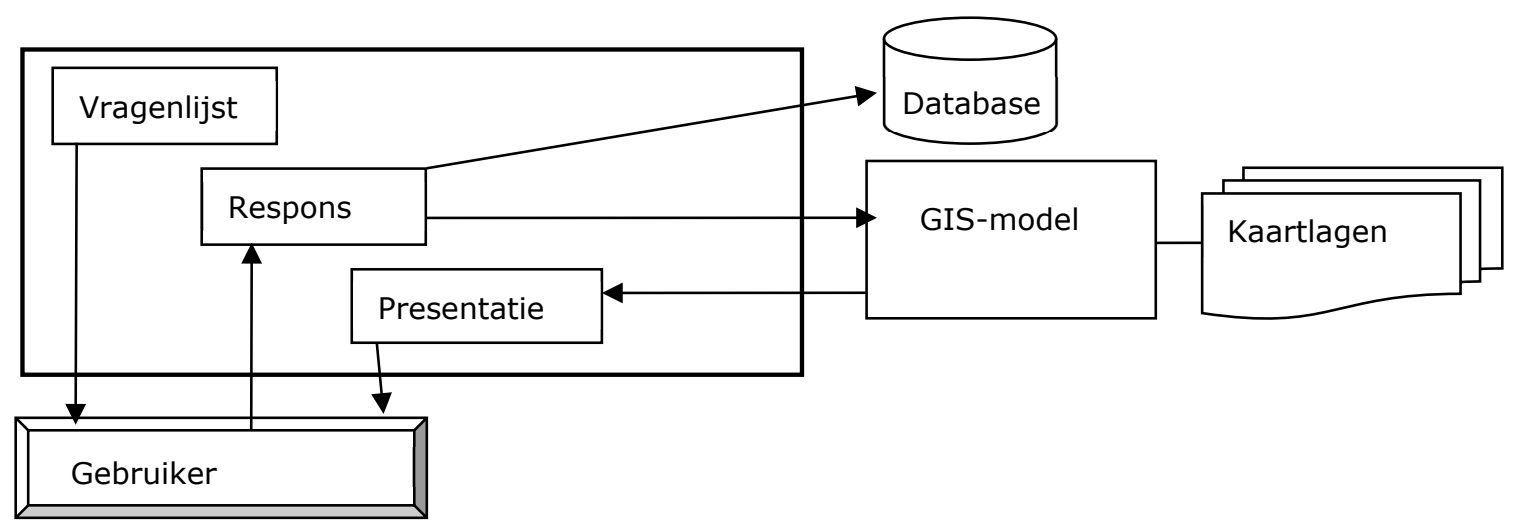

Figuur 1 Schematische weergave van de website.

Het basismateriaal voor het GIS-model bestaat uit afzonderlijke ruimtelijke bestanden per indicator ${ }^{1}$ (zie Figuur 1). De ruimtelijke eenheid is een gridcel van 500 bij 500 meter. Van elke indicator is de hoeveelheid berekend binnen een straal van vijf kilometer rond een centrale gridcel. Deze vijf kilometer is gekozen omdat het een gebied bestrijkt dat overeenkomt met de gemiddelde tijd voor een wandel- of fietstocht. Er zijn vijftien indicatoren waaruit bezoekers kunnen kiezen. Van elke indicator zijn drie foto's opgenomen en is een definitie gegeven ter verduidelijking. Bij elke indicator bestaat de mogelijkheid om in percentages aan te geven hoeveel van elke indicator moet voorkomen in het ideale landschap van de bezoeker. Tevens wordt gevraagd naar postcode, leeftijd en geslacht van de bezoeker en wordt gevraagd een rapportcijfer te geven over de aantrekkelijkheid van het landschap van zijn/haar eigen woonomgeving. Op basis van de ingevulde gegevens wordt een voor de bezoeker unieke kaart van Nederland gemaakt met daarop de gebieden waar hij/zij wel of juist niet moet zijn. De ingevulde gegevens zijn vanaf 7 februari 2006 opgeslagen. Voor dit project zijn alle gegevens gebruikt die tot en met 31 december 2015 zijn ingevuld. Dit komt neer op tien jaar. De gegevens zijn geanalyseerd met behulp van SPSS. Er is voor dit onderzoek een selectie gemaakt van inwoners van Zuid-Holland op basis van de ingevulde postcodes.

De website www.myplacetobe.eu kent eenzelfde opzet, maar is gericht op Europa. De indicatoren zijn dan ook gebaseerd op Europese GIS-bestanden. Maar ook op deze website wordt aan het eind gevraagd een rapportcijfer te geven over de aantrekkelijkheid van het landschap van zijn/haar eigen woonomgeving. Tevens wordt er gevraagd naar postcode, leeftijd en geslacht van de bezoeker. De ingevulde gegevens van deze website zijn vanaf 8 november 2010 opgeslagen. Voor dit project zijn alle gegevens gebruikt die tot en met 31 december 2015 zijn ingevuld. Dit komt neer op vijf jaar. Ook $\mathrm{nu}$ is een selectie gemaakt van inwoners van Zuid-Holland op basis van de ingevulde postcodes. De gegevens zijn toegevoegd aan de data van daarmoetikzijn.

\footnotetext{
1 Bos, Sloten, beken, rivieren en plassen, Heide-, zand- en duingebied, Natuurlijk grasland, moeras en riet, Zee en grote meren, Bewoningskernen, Halfopen agrarisch, Kleinschalig agrarisch, Open agrarisch, Bedrijven en industrie, Hoogteverschillen, Kastelen, oude boerderijen, terpen en andere cultuurhistorische elementen (bezienswaardigheden), Geluid van auto's, treinen en/of vliegtuigen (geluidbelasting), Hoogbouw, windturbines en elektriciteitsmasten (Horizonvervuiling), Drukte van recreatieve fietsers.
} 


\section{$1.5 \quad$ Werkwijze}

Respondenten zijn niet door Wageningen Environmental Research gevraagd de website te bezoeken. En ze worden ook niet betaald, zoals vaak bij panelonderzoek het geval is, maar hebben zelfstandig de keuze gemaakt om de website te bezoeken omdat ze ervan gehoord hebben of erover gelezen hebben of een link van iemand hebben gekregen. Analyses van het bezoekaantal laat een aantal uitschieters zien. Dit waren momenten waarop er een bericht over de website in dagbladen verscheen of artikelen in een tijdschrift, zoals HP/de Tijd of Quest of aandacht in (of websites van) een tv- of radioprogramma, zoals De Wereld Draait Door en Vroege vogels. Publiciteit helpt dus om bezoekersaantallen te krijgen. Niet alle bezoekers vullen hun voorkeuren in en maken ook een kaartje. Veel van de "bezoekers" zijn zoekrobots. Circa 15\% van de bezoekers die "langskomen op de website" is nieuwsgierig naar hun ideale gebied en maakt daadwerkelijk een kaartje. Zodra er een kaartje gemaakt is, worden de gegevens opgeslagen. De meeste bezoekers maken één kaartje. Gemiddeld heeft elke bezoeker 1,5 kaartje gemaakt. Voor de analyse is alleen de eerste "invulling" van de voorkeuren gebruikt, omdat dit waarschijnlijk het meest overeenkomt met de primaire voorkeuren. Na het zien van het kaartje gaan sommige bezoekers "spelen" met de website en maken dan aparte kaartjes. Dit kan leiden tot een "vervuiling" van de daadwerkelijke voorkeuren. De analyse van dit rapport heeft dus betrekking op het eerste kaartje van de bezoekers.

Om unieke personen te selecteren voor de analyse, is geselecteerd op de combinatie van datum van bezoek, geslacht, leeftijd en postcode. Deze combinatie geeft dan een uniek record. De aanname is dat dit ook een uniek persoon is. De kans dat iemand op dezelfde dag met hetzelfde geslacht en leeftijd en afkomstig uit hetzelfde postcodegebied de website bezoekt is klein, maar niet volledig te negeren. Toch is hier van uitgegaan. Dit betekent echter wel dat eenzelfde persoon die op een andere datum de website nog eens bezoekt, toch als een nieuw unieke persoon wordt gezien. Dit geldt ook voor iemand die zowel in 2006 als in 2009 de website heeft bezocht, omdat de leeftijd dan hoger is. Weliswaar "onthoudt" de computer de laatste invulling bij hernieuwd bezoek, maar het kan zijn dat de bezoeker dan toch zijn of haar leeftijd aanpast. Toch is het aantal terugkerende bezoekers klein. Een analyse van de website laat zien dat slecht $1 \%$ een terugkerende bezoeker is. Het is ook mogelijk dat bezoekers beide websites hebben bezocht en op beide websites hun rapportcijfer over de aantrekkelijkheid van het landschap van zijn/haar eigen woonomgeving hebben ingevuld. Doordat er op beide websites een uniek ID-nummer wordt aangemaakt, is het niet mogelijk deze dubbeltelling te achterhalen.

$\mathrm{Er}$ is voor dit onderzoek een selectie gemaakt van inwoners van Zuid-Holland op basis van de ingevulde postcodes. In Zuid-Holland hebben in de afgelopen tien jaar 8.935 unieke bezoekers de websites bezocht (Tabel 1) en een kaartje gemaakt waarbij het merendeel (85\%) afkomstig is van de website daarmoetikzijn.

Tabel 1 Aantal unieke bezoekers.

\begin{tabular}{lll} 
Website & Aantal & Percentage \\
Daarmoetikzijn & 7.593 & 85 \\
\hline Myplacetobe & 1.342 & 15 \\
\hline Totaal & 8.935 & 100 \\
\hline
\end{tabular}




\section{De bezoekers}

\subsection{Bezoek van de afgelopen tien jaar}

Figuur 2 laat duidelijk zien dat de belangstelling voor de websites in Zuid-Holland aan het dalen is, met een dieptepunt in 2012 toen er slechts 126 bezoekers ${ }^{2}$ uit Zuid-Holland waren. Dit is vooral het gevolg van het feit dat veel "links" bij andere websites niet meer boven aan de webpages staan en mensen moeilijker de websites kunnen vinden. In 2013 en 2014 is er een opleving van het bezoek te bespeuren. Dat komt vooral door publicaties van de website myplacetobe in het tijdschrift Quest.

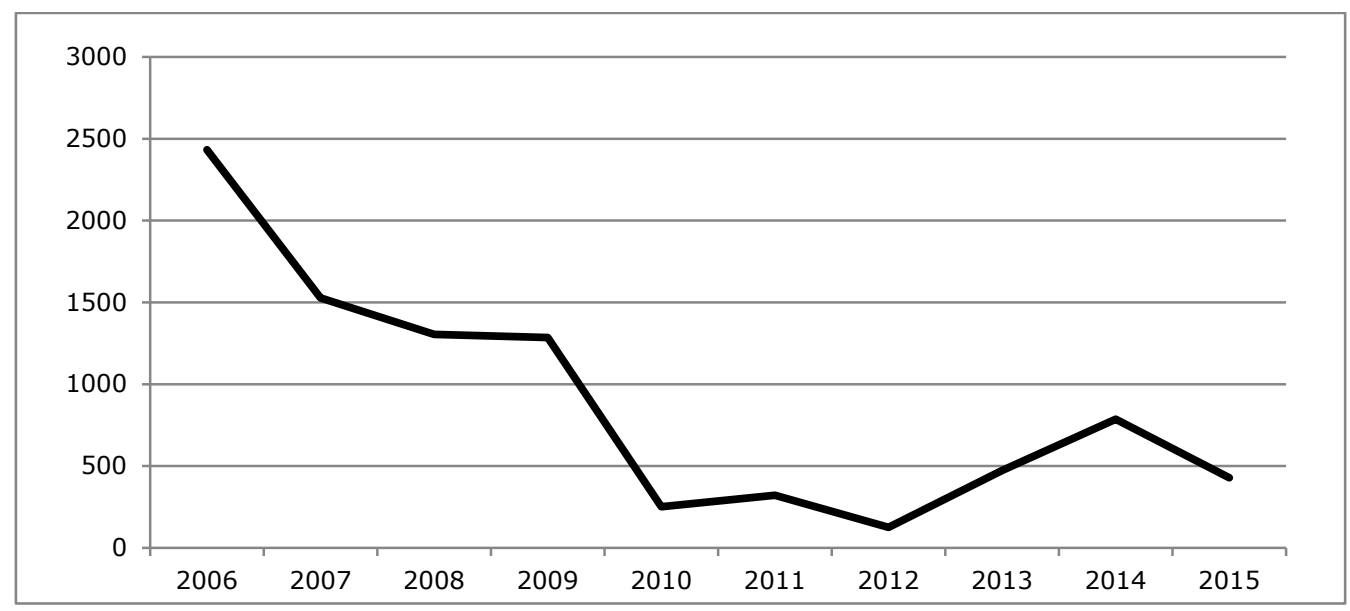

Figuur 2 Aantal bezoekers uit Zuid-Holland aan de websites daarmoetikzijn en myplacetobe per jaar.

\subsection{Persoonlijke kenmerken}

Op de websites worden drie persoonlijke kenmerken gevraagd aan de respondenten, namelijk geslacht, leeftijd en postcode van hun woonplaats.

Tabel 2 Verdeling geslacht bezoekers ${ }^{3}$ per jaar.

\begin{tabular}{|c|c|c|c|c|c|}
\hline \multirow[t]{2}{*}{ Jaar } & \multirow{2}{*}{$\frac{\text { Man }}{N}$} & \multicolumn{3}{|c|}{ Vrouw } & \multirow[t]{2}{*}{ Totaal } \\
\hline & & $\%$ & $\mathbf{N}$ & $\%$ & \\
\hline 2006 & 1672 & 69 & 756 & 31 & 2428 \\
\hline 2008 & 688 & 53 & 618 & 47 & 1306 \\
\hline 2009 & 719 & 56 & 565 & 44 & 1284 \\
\hline 2012 & 57 & 47 & 65 & 53 & 122 \\
\hline 2013 & 137 & 59 & 97 & 41 & 234 \\
\hline 2014 & 38 & 53 & 34 & 47 & 72 \\
\hline 2015 & 19 & 41 & 27 & 59 & 46 \\
\hline
\end{tabular}

\footnotetext{
2 Voor statistische analyses is dit aantal voldoende. Voor ruimtelijke analyses op gemeentelijk niveau beperkt.
}

3345 bezoekers hebben geen geslacht ingevuld. 
De website is meer een "mannending", want gemiddeld is $60 \%$ een man (Tabel 2). Dit percentage wisselt in de loop der jaren sterk. In hoeverre het een probleem is dat meer mannen de website hebben bezocht, is afhankelijk van het feit of mannen andere meningen en voorkeuren hebben voor het landschap dan vrouwen. Is dit niet het geval, dan is het voor een analyse van de landschapskenmerken niet erg dat er meer mannen de vragen op de website hebben ingevuld dan vrouwen. Op dit aspect wordt later verder ingegaan.

De gemiddelde leeftijd over de tien jaar is 44 jaar. De gemiddelde leeftijd is de laatste twee jaar flink afgenomen, wellicht door de invloed van de Quest-lezers die in het algemeen jonger zijn.

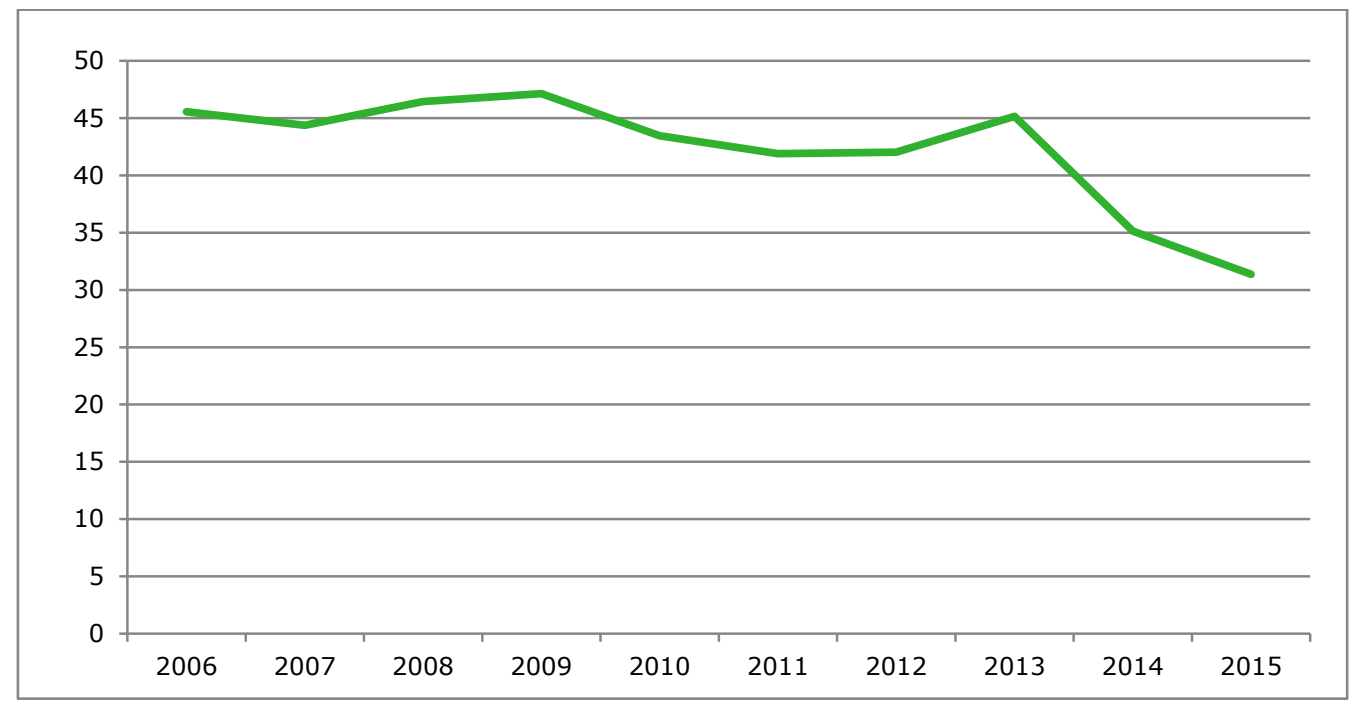

Figur 3 Gemiddelde leeftijd bezoekers uit Zuid-Holland aan de websites daarmoetikzijn en myplacetobe per jaar.

Wanneer de leeftijd van de bezoekers wordt vergeleken met de leeftijd van de inwoners van ZuidHolland $^{4}$, dan blijkt dat de websites een sterke oververtegenwoordiging heeft in de leeftijdsklasse 40 tot en met 60 jaar. Jongeren en ouderen zijn minder vertegenwoordigd.

Tabel 3 Verdeling (\%) leeftijdsklassen van inwoners van Zuid-Holland volgens opgave van het CBS en bezoekers aan de websites uit Zuid-Holland.

\begin{tabular}{lrr} 
Leeftijdsklasse & CBS & websites \\
\hline Jonger dan 10 jaar & 12 & 0 \\
\hline 10 tot 20 jaar & 12 & 4 \\
\hline 20 tot 30 jaar & 13 & 18 \\
\hline 30 tot 40 jaar & 14 & 17 \\
\hline 40 tot 50 jaar & 15 & 21 \\
\hline 50 tot 60 jaar & 14 & 24 \\
\hline 60 tot 70 jaar & 10 & 13 \\
\hline 70 tot 80 jaar & 7 & 3 \\
\hline 90 tot 90 jaar & 3 & 0 \\
\hline Totaal of ouder & 1 & 0 \\
\hline
\end{tabular}

\footnotetext{
${ }^{4}$ De gemiddelde leeftijd tussen 2006 en 2016 voor de inwoners uit Zuid-Holland is gebruikt op basis van CBS-data.
} 
Aan de bezoekers is ook de postcode van hun woonplaats gevraagd. Figuur 4 laat de spreiding zien over Zuid-Holland. De Zuid-Hollandse gemeenten zijn goed gedekt bij de spreiding van de woonplaats van de website-bezoeker. De ruimtelijke spreiding van de inwoners komt overeen met die van het

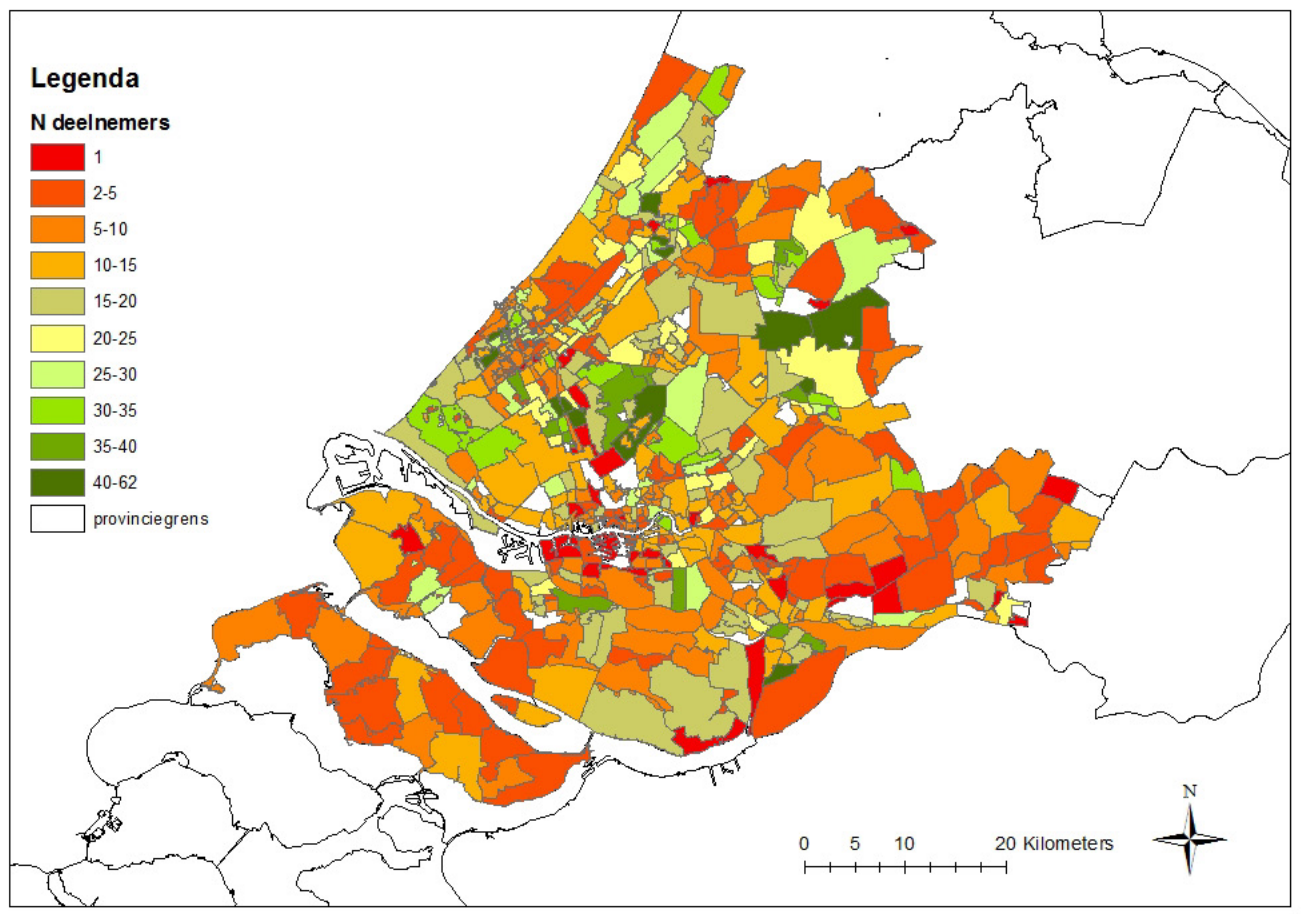

Figuur 4 Ruimtelijke verdeling van de bezoekers aan de websites de afgelopen jaren op 4-positie postcodeniveau.

CBS. Er is een correlatie van 0,95 tussen de ruimtelijke spreiding van de bezoekers en de daadwerkelijke woonplaats van inwoners van Zuid-Holland via de opgave van gemeenten van het CBS. Er zijn relatief weinig regio's waar de websites niet door een bewoner is gebruikt. De meeste bezoekers zijn afkomstig uit Den Haag, Rotterdam, Delft, Bodegraven, Berkel en Rodenrijs en Leiden.

\subsection{Representativiteit}

Afhankelijk van de doelstelling is het belangrijk of een steekproef representatief is voor de ZuidHollandse bevolking. Belangrijk hierbij is de kans dat iedere Zuid-Hollander in de steekproef kan worden opgenomen. In dit project is hierover een aantal kanttekeningen te maken. Alleen mensen met een internetverbinding hebben de mogelijkheid om deel te nemen aan dit project. Ook moeten ze de Nederlandse taal machtig zijn. Daarnaast zal niet iedereen geïnteresseerd zijn in het onderwerp landschap. De steekproef is daarom select. Mensen die wel in landschap geïnteresseerd zijn, zijn wellicht oververtegenwoordigd. De resultaten over de mening van de aantrekkelijkheid van het landschap moeten dus in het licht van deze kanttekeningen worden gezien. De websites hebben alleen de persoonlijke kenmerken leeftijd, geslacht en postcode waarop de representativiteit kan worden onderzocht. En dan is het belangrijk of er een significant verschil bestaat tussen deze kenmerken en hun waardering voor het landschap. Uit de resultaten blijkt dat de verdeling van de leeftijd en het geslacht niet volledig overeenkomt met de daadwerkelijke verdeling. Bij de resultaten over de aantrekkelijkheid van het landschap in hun directe woonomgeving zal hier nader op worden ingegaan. De ruimtelijke verdeling van de bezoekers is wel in overeenstemming met de daadwerkelijke verdeling. Ruimtelijk is de steekpoef dus wel representatief.

$\mathrm{Bij}$ het leggen van statistische relaties is het minder belangrijk of de steekproef representatief is. 


\section{De Resultaten}

\subsection{Aantrekkelijkheid}

De bezoekers uit Zuid-Holland hebben met een rapportcijfer aangegeven hoe aantrekkelijk ze het landschap direct rond hun woonplaats vinden. De gemiddelde aantrekkelijkheid van het landschap rond hun eigen woonplaats over de afgelopen tien jaar is een 6,1 , gebaseerd op de scores uit daarmoetikzijn en myplacetobe. De gemiddelde aantrekkelijkheid is wel dalende in deze jaren, na een aanvankelijke stijging (Figuur 5).

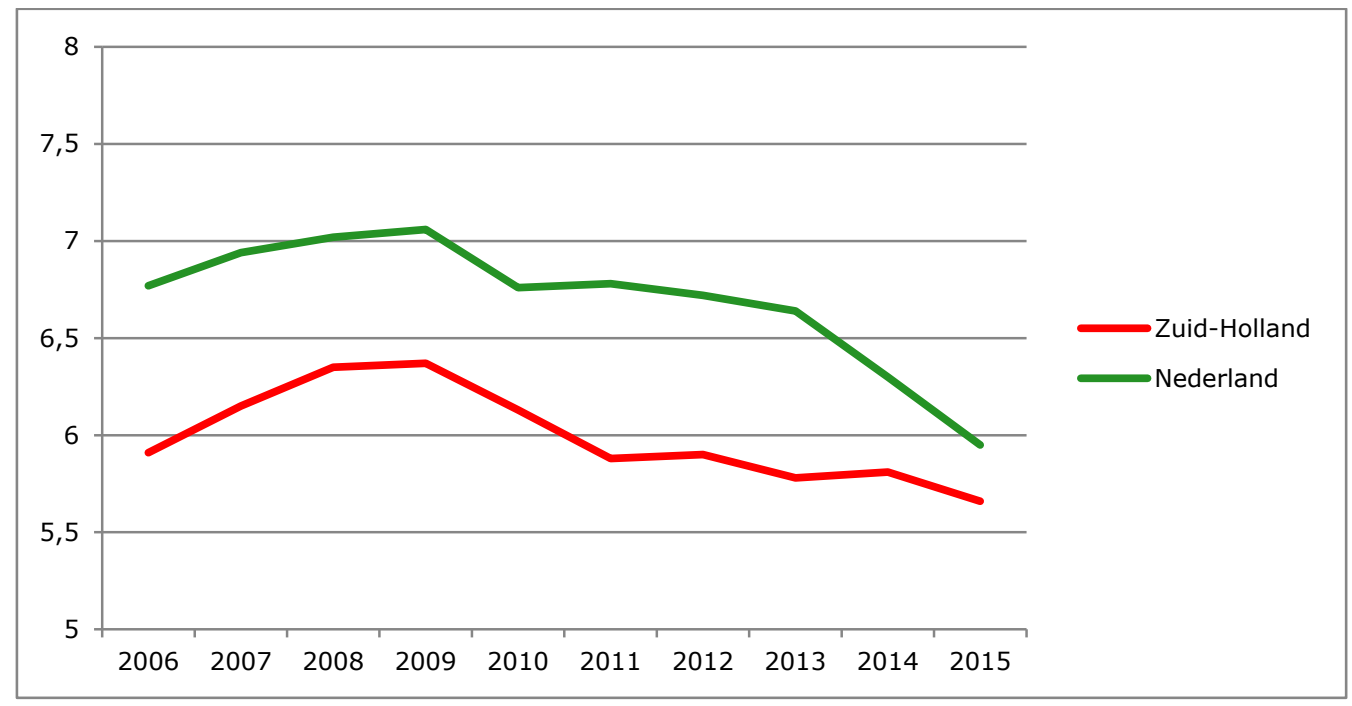

Figuur $5 \quad$ Gemiddelde aantrekkelijkheid van het landschap in de directe woonomgeving per jaar op basis van de websites daarmoetikzijn en myplacetobe.

De trend in Zuid-Holland volgt de landelijke trend. Ook voor heel Nederland is er na een stijging vanaf 2009 een daling ingezet. Vanaf 2011 geven de Zuid-Hollandse bezoekers gemiddeld een onvoldoende. De gemiddelde waardering in Zuid-Holland ligt wel al die jaren lager dan de landelijke waardering. De landelijke waardering via deze websites ligt weer lager dan uit ander onderzoek naar voren komt. In 2006 gaf de Nederlandse bevolking het landschap gemiddeld het rapportcijfer 7,3 (Crommentuijn, 2006). Wellicht speelt hier de plek van de vraag op de website een rol. Bezoekers mogen eerst hun ideale landschap samenstellen en worden dan gevraagd een oordeel te geven over hun eigen landschap. Het kan zijn dat de bezoekers dan kritischer zijn. Er wordt niet gevraagd naar tevredenheid. Het kan dus zijn dat bezoekers het landschap minder aantrekkelijk vinden, maar er toch tevreden mee zijn.

Circa een derde van de bezoekers (32\%) uit Zuid-Holland geeft een onvoldoende (lager dan 6) aan het landschap rond de eigen woonplaats. Lage rapportcijfers worden vooral door Rotterdammers gegeven. Veel gebieden met een onvoldoende liggen in een strook in het midden van de provincie; van Den Haag via Pijnacker-Nootdorp, Berkel en Rodenrijs, Bergschenhoek, Rotterdam, Ridderkerk naar Dordrecht, zoals Figuur 6 laat zien. Ofwel een strook rond de A12, A20, A15 en A16. Het gemiddelde rapportcijfer over de hele provincie wordt dan ook grotendeels bepaald door inwoners van Den Haag en Rotterdam, die sterk aanwezig zijn in het bestand. 


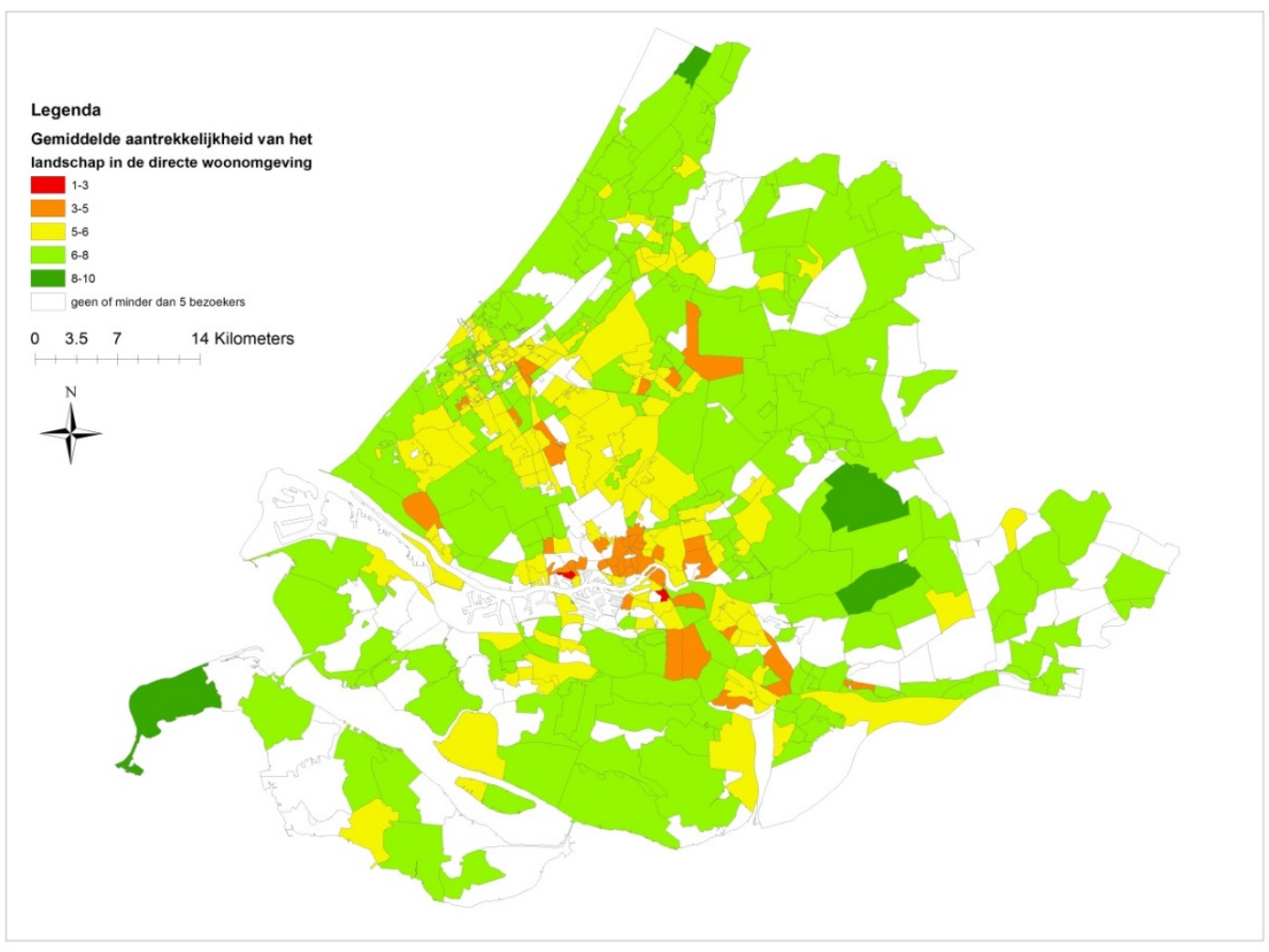

Figur 6 Gemiddelde aantrekkelijkheid van het landschap in de directe woonomgeving per 4positie postcodegebied met minimaal 5 bezoekers.

Want wanneer naar het grondoppervlak van de gehele provincie wordt gekeken en waar rapportcijfers over bekend zijn, blijkt dat $80 \%$ van het grondoppervlak van de provincie een voldoende krijgt. Ruimtelijk gezien krijgt dus het grootste deel van het landschap een voldoende. De Noordzeekust doet het goed; de Zilk in gemeente Noordwijkerhout scoort relatief het hoogst met een gemiddelde van 8,9 door 7 respondenten. En ook Ouddorp op Goeree-Overflakkee scoort gemiddeld hoog met een 8,6 door 10 respondenten.

Er is een significant verschil tussen de aantrekkelijkheidsscore van het landschap en geslacht en leeftijd. Vrouwen vinden het landschap in hun directe woonomgeving aantrekkelijker ${ }^{5}$ dan mannen.

Tabel 4 Gemiddelde aantrekkelijkheid landschap in woonomgeving van bezoekers aan beide websites per leeftijdsklasse.

\begin{tabular}{lr} 
Leeftijdsklasse & Gemiddelde score voor aantrekkelijkheid \\
Jonger dan 10 jaar & 5.0 \\
\hline 10 tot 20 jaar & 5.9 \\
\hline 20 tot 30 jaar & 5.7 \\
\hline 30 tot 40 jaar & 5.9 \\
\hline 40 tot 50 jaar & 6.1 \\
\hline 50 tot 60 jaar & 6.2 \\
\hline 60 tot 70 jaar & 6.4 \\
\hline 70 tot 80 jaar & 6.5 \\
\hline 80 tot 90 jaar & 6.8 \\
\hline 90 jaar of ouder & 5.2
\end{tabular}

\footnotetext{
${ }^{5}$ Correlatie van 0.034 bij $p<0,01$
} 
De relatief lage gemiddelde score voor de aantrekkelijkheid kan dus komen omdat mannen oververtegenwoordigd zijn. Ook naarmate men ouder wordt, stijgt de score voor de aantrekkelijkheid $^{6}$. Ook zijn ouderen ondervertegenwoordigd en die geven juist een hoger rapportcijfer. Een groep die ook ondervertegenwoordigd is en relatief een hoger rapportcijfer geeft, is de groep van 10 tot 20 jaar.

\subsection{Verklaringen aantrekkelijkheid}

Van elk postcodegebied is een straal van 5 kilometer getrokken om de hoeveelheid van een aanwezig landschapstype en aanvullende kenmerken te berekenen. Vervolgens zijn deze resultaten gecorreleerd met de aantrekkelijkheidsscore. Uit Tabel 5 blijkt dat bijna alle kenmerken een significante relatie hebben met de aantrekkelijkheidsscore, alleen het landschapstype kleinschalig agrarisch gebied heeft geen significante relatie met de score. Niet opvallend is dat bedrijfsterreinen, industriegebieden, geluid van auto, trein en vliegtuig, horizonvervuiling en drukte met recreatieve fietsers een negatieve relatie hebben met deze score. Dat wil zeggen hoe meer bedrijverterreinen er daadwerkelijk voorkomen, hoe lager het rapportcijfer is dat de bezoeker heeft gegeven aan de aantrekkelijkheid van het landschap in de woonomgeving. Ook bewoningskernen hebben deze negatieve relatie. Uit het onderzoek in 2006 (Crommentuijn, 2006) zag men het landschap in zijn omgeving ook negatief veranderen door verstedelijking (aanleg van infrastructuur, bedrijfsterreinen en woonwijken). Opvallend is dat ook bossen en sloten, beken, rivieren en plassen deze negatieve relatie hebben ${ }^{7}$. Dat wil dus zeggen dat hoe meer van dit landschapstype voorkomt, hoe lager de aantrekkelijkheidsscore. Het is gissen naar een verklaring hiervoor. Wellicht dat de bezoekers meer een voorkeur hebben voor open agrarisch gebied. Dit landschapstype heeft, evenals halfopen agrarisch gebied, een positieve relatie met de aantrekkelijkheidsscore. Dus hoe meer van dit type landschap, hoe aantrekkelijker men het vindt. In paragraaf 3.3 zal hier nader op worden ingegaan.

Tabel 5 Relatie landschapstypen, aanvullende kenmerken en aantrekkelijkheidsscore.

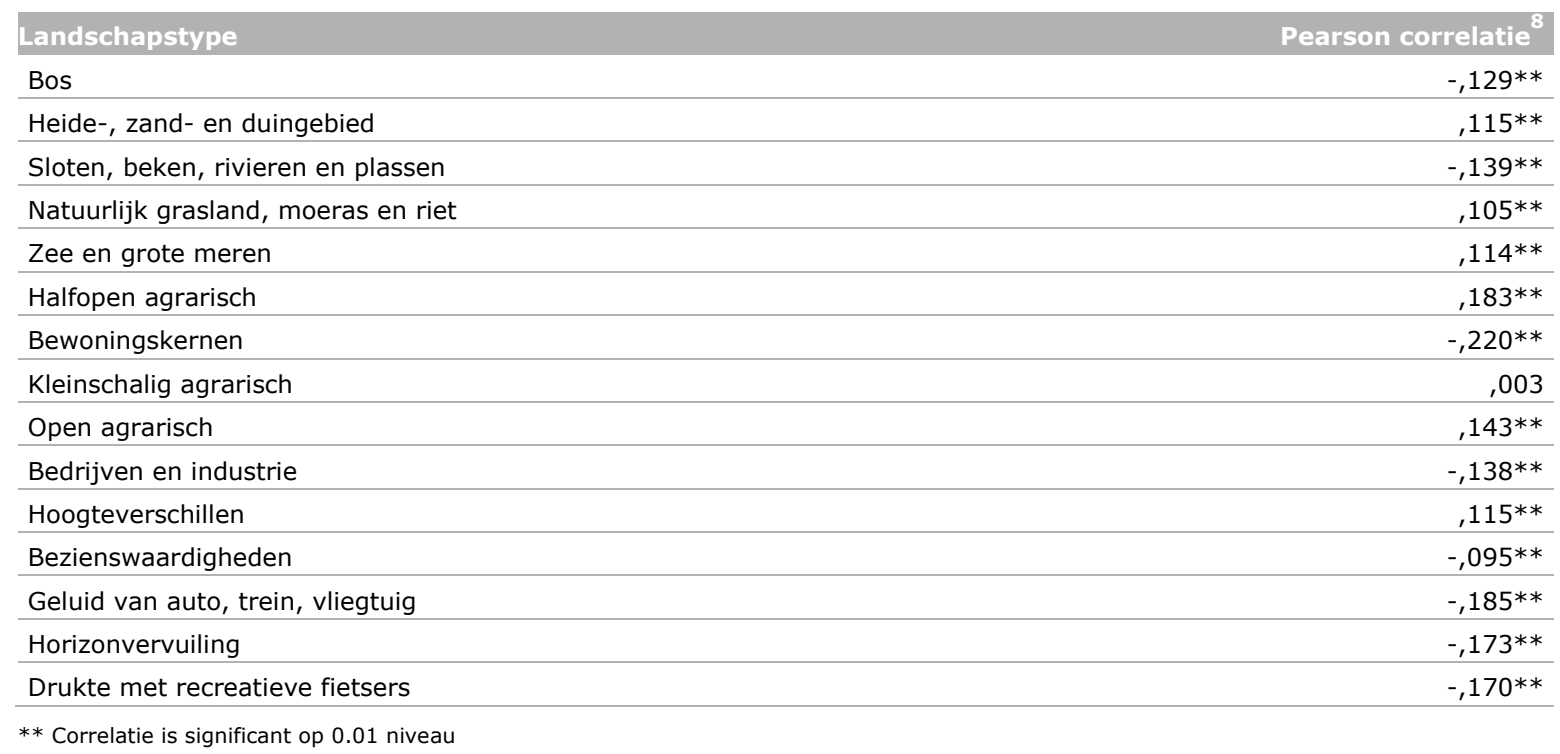

\footnotetext{
6 Correlatie van 0,115 bij $\mathrm{p}<0,01$

7 In veel (inter)nationaal onderzoek is er juist een positieve relatie.

8 Met behulp van correlatie kan getoetst worden of er een lineair verband is tussen de aantrekkelijkheid en de landschapstypen. Een perfecte positieve samenhang wordt bereikt bij een waarde van 1; een negatieve bij een waarde -1 . In deze tabel is dus sprake van een zeer zwak positief dan wel negatief verband. Significant wil zeggen dat het geen toeval is.
} 
Ook heide-, zand- en duingebieden, hoogteverschillen, zee en grote meren en natuurlijk grasland, moeras en riet hebben een positieve relatie met de aantrekkelijkheidsscore. Dus hoe meer van dat type voorkomt, hoe hoger het rapportcijfer voor de aantrekkelijkheid is.

De opbouw van het landschap in de woonomgeving van de bezoeker is bekend. Daarmee is het mogelijk om te achterhalen in hoeverre het aanwezige landschap en aanvullende kenmerken in de omgeving de aantrekkelijkheidsscore kunnen verklaren. Om dit te berekenen, is een stepwise lineaire regressieanalyse uitgevoerd. Het blijkt (Tabel 6) dat over de jaren heen de aantrekkelijkheidsscore voor $8 \%$ verklaard kan worden door de aanwezige landschapstypen en aanvullende kenmerken. Per jaar schommelt de verklaarde variantie ook rond de $8 \%$. Opvallend is dat het vooral kenmerken zijn die een negatieve bijdrage leveren aan de score. In de tabel wordt het kenmerk met de grootste bijdrage als eerste genoemd. Vooral bebouwing is door de jaren heen verantwoordelijk voor de score. Hoe meer bebouwing, hoe lager de aantrekkelijkheidsscore. Ook bedrijventerreinen, industriegebieden, horizonvervuiling en geluidbelasting leveren een negatieve bijdrage aan de score, evenals bossen. Heide-, zand- en duingebieden leveren daarentegen vooral een positieve bijdrage aan de aantrekkelijkheidsscore, evenals hoogteverschillen.

Het lijkt er dus sterk op dat vooral kenmerken die minder gewaardeerd worden aan het landschap deels verantwoordelijk zijn voor de aantrekkelijkheidsscore. Er moet wel bedacht worden dat een verklaarde variantie van $8 \%$ niet erg hoog is. Er zijn dus blijkbaar meer kenmerken die de aantrekkelijkheid van het landschap in de omgeving bepalen.

Tabel 6 Verklaarde variantie (\%) en verantwoordelijke indicatoren door de jaren heen.



Dik schuin= negatieve bijdrage; recht= positieve bijdrage

Wanneer naar de ruimtelijke verdeling van gebieden met een onvoldoende voor de aantrekkelijkheid wordt gekeken (Figuur 6), blijken deze onvoldoendes vooral in gebieden te liggen met veel bebouwing, bedrijventerreinen, industriegebieden, horizonvervuiling en geluidbelasting. Dit zijn ook de gebieden waar relatief veel bezoekers wonen. De gemiddelde aantrekkelijkheid voor de hele provincie wordt dus voor een groot deel door deze groep bezoekers bepaald.

\subsection{Relatie werkelijk en gewenst aanbod}

Er wordt vaak gesteld dat mensen een voorkeur hebben voor een landschap waar ze zijn opgegroeid of waar ze wonen. Om dit te onderzoeken, is gezocht naar een relatie tussen het werkelijke aanbod en het gewenste aanbod van landschapstypen en aanvullende kenmerken. Uit Tabel 7 blijkt dat deze stelling deels waar is. Bezoekers die in een gebied wonen met veel (half)open agrarisch gebied, hebben daar ook een voorkeur voor in hun ideale landschap. Dit geldt ook voor heide-, zand- en duingebieden en de zee en grote meren. Maar bezoekers die in een gebied wonen met veel bebouwing vinden het aantrekkelijk om ook in hun ideale gebied bewoningskernen te hebben. Opvallend zijn de resultaten voor bedrijventerreinen en industriegebieden. Ook daar is een positieve relatie tussen 
werkelijk aanbod en gewenst. Misschien speelt de werkgelegenheid dat gepaard gaat met dit type een rol bij de waardering. Ook de relatie met horizonvervuiling is opvallend. Hoe meer horizonvervuiling in de woonomgeving van de bezoeker aanwezig is, hoe minder horizonvervuiling hij/zij in het ideale landschap wil zien. Vermeldingswaardig is ook het feit dat er geen relatie gevonden is tussen het werkelijk aanbod aan bos en een voorkeur voor bos. Hetzelfde geldt ook voor sloten, beken, rivieren en plassen.

Tabel 7 Correlatie tussen gewenst aanbod en werkelijke aanbod.

Voorkeur landschapstype

Werkelijk aanbod

Heide-, zand- en duingebied

Zee en grote meren

Halfopen agrarisch

Bewoningskernen

Open agrarisch

** Correlatie is significant op 0.01 niveau; * Correlatie is significant op 0.05 niveau. Er is sprake van een zeer zwakke samenhang tussen de werkelijk en gewenst landschapstype. 


\section{Voorkeuren}

\section{$4.1 \quad$ Inleiding}

$\mathrm{Er}$ is in zijn algemeenheid gevraagd om een ideaal landschap samen te stellen voor de recreatieactiviteiten die men wil ondernemen. $\mathrm{Er}$ is niet gevraagd hoe het ideale landschap in de directe woonomgeving eruit zou moeten zien. Een ideaal landschap is het streven, maar dat wil niet zeggen dat je dat ook in de eigen omgeving wilt hebben. Toch is het wel mogelijk om hier een richting uit te halen voor de eigen omgeving, maar dan wel met deze kanttekening.

\subsection{Het ideale landschap}

De voorkeuren waaruit een ideaal landschap moet bestaan, is weergegeven in Tabel 8 . Bij de analyse zijn alleen de voorkeuren van Zuid-Hollanders die de website daarmoetikzijn hebben bezocht. De landschapskenmerken uit de website myplacetobe zijn anders opgebouwd, zodat deze voorkeuren niet vergelijkbaar zijn met die van daarmoetikzijn. De aanleiding om myplacetobe te bezoeken, is ook anders. Men is daar meer op zoek naar de ideale vakantiebestemming in Europa. Zoals in ander onderzoek (Goossen et al, 2011) komt ook nu het bos als meest favoriete landschap naar voren. Circa $67 \%$ van de bezoekers wil in ieder geval een zekere hoeveelheid bos in zijn/haar ideale landschap hebben. Dit is opvallend, omdat in paragraaf 3.2 werd aangegeven dat er een negatieve relatie bestaat tussen het werkelijk aanbod aan bos en het rapportcijfer voor de aantrekkelijkheid van het landschap. Ook heide-, zand- en duingebieden scoren hoog (gemiddeld 57\%) in het ideale landschap. Zuid-Hollanders houden van water, want rivieren, kanalen en plassen staan op de derde plaats (57\%), maar ook natte natuurgebieden zoals natuurlijk grasland, moeras en riet (44\%) en de Noordzee en grote meren (40\%) doen het goed.

Industriegebieden worden naar verwachting gemiddeld het minst favoriet gevonden. Opvallend is het resultaat voor agrarische gebieden. Van de drie typen agrarische gebieden heeft het halfopen agrarisch gebied de meeste respondenten (35\%) die er een zekere hoeveelheid van wil hebben. Het open agrarisch gebied is het minst populair. Circa $10 \%$ van de bezoekers wil zelfs helemaal geen open agrarisch gebied in hun ideale landschap.

\section{Tabel 8 Gemiddelde voorkeur landschapstypen.}

\begin{tabular}{llll} 
Landschapstype & Wil het hebben & Absoluut niets & Maakt niet uit \\
Bos & 66,8 & 4,4 & 28,8 \\
\hline Heide-, zand- en duingebied & 57,1 & 7,8 & 35,1 \\
\hline Sloten, beken, rivieren en plassen & 56,8 & 6,6 & 36,6 \\
\hline Natuurlijk grasland, moeras en riet & 44,4 & 8,9 & 46,7 \\
\hline Zee en grote meren & 39,7 & 9,3 & 51,0 \\
\hline Halfopen agrarisch & 35,2 & 7,5 & 57,3 \\
\hline Bewoningskernen & 34,6 & 9,8 & 55,6 \\
\hline Kleinschalig agrarisch & 32,7 & 8,8 & 58,5 \\
\hline Open agrarisch & 28,8 & 10,4 & 60,8 \\
\hline Bedrijven en industrie & 11,5 & 19,5 & 69,0 \\
\hline
\end{tabular}

Er komt een soortgelijk beeld naar voren wanneer gevraagd wordt naar de hoeveelheid van een type landschap in hun ideale gebied. In Tabel 9 staan de gemiddelden (exclusief "maakt niet uit") van elk landschapstype. De gemiddelde Zuid-Hollander wil over de afgelopen 10 jaar het liefst $31 \%$ bos hebben in zijn/haar ideale landschap. Maar er moeten ook zee en meren aanwezig zijn (circa $21 \%$ ). 
Het ideale landschap moet verder $18 \%$ heide-, zand- of duingebied bevatten. Ook sloten, beken, rivieren en plassen en natuurlijk grasland, moeras en riet moeten voor $14 \%$ onderdeel uitmaken van het ideale landschap. Het blijkt dat de gewenste hoeveelheid kleinschalig agrarisch gebied bijna even groot is als de hoeveelheid halfopen agrarisch gebied. Ook nu scoren industriegebieden (5\%) en open agrarisch gebied (13\%) laag in vergelijking tot andere indicatoren, evenals bebouwing (13\%).

Tabel 9 Gewenste gemiddelde hoeveelheid (\%) per landschapstype 9

\begin{tabular}{ll} 
Landschapstype & Gemiddeld $(\%)$ \\
Bos & 31 \\
\hline Zee en grote meren & 21 \\
\hline Heide-, zand- en duingebied & 18 \\
\hline Halfopen agrarisch & 16 \\
\hline Kleinschalig agrarisch & 15 \\
\hline Sloten, beken, rivieren en plassen & 14 \\
\hline Natuurlijk grasland, moeras en riet & 14 \\
\hline Bebouwing & 13 \\
\hline Open agrarisch & 13 \\
\hline Bedrijven en industrie & 5 \\
\hline
\end{tabular}

Naast het landschap kunnen nog andere aanvullende kenmerken, zoals hoogteverschillen en bezienswaardigheden (in de vorm van kastelen, oude boerderijen, terpen en andere cultuurhistorische elementen) worden gekozen om een ideaal landschap te creëren. Naast "maakt niet uit" kan men kiezen op een 100-puntenschaal van "absoluut niks" tot "heel veel".

Storende elementen kunnen afbreuk doen aan een landschap. Het ontbreken van deze storende elementen kan een meerwaarde betekenen voor het landschap. Naast "maakt niet uit" kan men kiezen op een 100 puntenschaal van "niet storend" tot "zeer storend".

Tabel 10 laat zien dat ruim de helft van de website-bezoekers uit Zuid-Holland enige mate van reliëf en twee derde van de bezoekers bezienswaardigheden wil hebben.

Tabel 10 Verdeling aanvullende elementen.

\begin{tabular}{lrrr} 
Aanvullende kenmerken & Wil het hebben & Absoluut niets & Maakt niet uit \\
Hoogteverschillen & 57,1 & 5,4 & 37,5 \\
\hline Bezienswaardigheden & 65,6 & 3,1 & 31,3 \\
\hline
\end{tabular}

Slechts $5 \%$ wil absoluut geen reliëf, maar een vlak land. $3 \%$ wil absoluut geen bezienswaardigheden in de vorm van kastelen, oude boerderijen, terpen en/of andere cultuurhistorische elementen.

De mening over storende elementen in het landschap wordt zeer vaak ingevuld. Duidelijk laat Tabel 11 zien dat 76\% van de website-bezoekers in Zuid-Holland het in enige mate storend vindt om geluid te horen van auto's, treinen en/of vliegtuigen. Slechts $3 \%$ vindt het absoluut niet storend en $21 \%$ maakt het niet uit. Ook horizonvervuiling in de vorm van hoogbouw, windturbines en elektriciteitsmasten wordt door $70 \%$ als enige mate van storend ervaren. Circa $4 \%$ vindt dit niet storend en $26 \%$ maakt het niet uit. Drukte van recreatieve fietsers is relatief het minst storend. Iets meer dan de helft (57\%) vindt het in enige mate storend. Van de websitebezoekers vindt bijna $7 \%$ het absoluut niet storend en $36 \%$ maakt het niet uit.

\footnotetext{
${ }^{9}$ Het totaal is geen $100 \%$, omdat de keuze "maakt niet uit" bij elk landschapstype een grote of kleine rol heeft gespeeld.
} 
Tabel 11 Verdeling storende elementen.

\begin{tabular}{llll} 
Aanvullende kenmerken & Storend & Niet storend & Maakt niet uit \\
Geluid van auto, trein, vliegtuig & 76,1 & 3,4 & 20,5 \\
\hline Horizonvervuiling & 70,1 & 3,5 & 26,4 \\
\hline Drukte met recreatieve fietsers & 56,6 & 6,9 & 36,5 \\
\hline
\end{tabular}

Er komt een soortgelijk beeld naar voren als gevraagd wordt naar de mate van hoeveelheid van een aanvullend kenmerk in hun ideale gebied. In Tabel 12 staan de gemiddelden van de aanvullende kenmerken.

Tabel 12 Gemiddelde aanvullende elementen.

\begin{tabular}{ll} 
Aanvullende kenmerken & Gemiddeld $(\%)$ \\
Bezienswaardigheden & 49 \\
\hline Hoogteverschillen & 36 \\
\hline & \\
\hline Geluid van auto, trein, vliegtuig & 65 \\
\hline Horizonvervuiling & 58 \\
\hline Drukte van recreatieve fietsers & 38
\end{tabular}

Tabel 12 laat zien dat de gemiddelde websitebezoeker in Zuid-Holland graag redelijk wat bezienswaardigheden en reliëf wil hebben in het favoriete landschap. Gemiddeld genomen hoeft het voor de websitebezoeker niet helemaal stil te zijn in het ideale gebied, maar er moet zeker niet te veel geluid van auto's, treinen en vliegtuigen voorkomen. Dit geldt ook voor horizonvervuiling. Voor de gemiddelde websitebezoeker mag het best een beetje druk zijn met fietsers in zijn/haar ideale gebied.

\subsection{Voorkeuren door de jaren heen}

Het is interessant om te onderzoeken of er in de tien jaar dat de website daarmoetikzijn bestaat de voorkeuren veranderd zijn. We moeten ons wel realiseren dat de websitebezoekers telkens andere mensen zijn. Ook het totale aantal per jaar is verschillend.

Wanneer we de landschapskenmerken verdelen onder de clusters 'natuurlijk', 'agrarisch', 'water' en 'antropogeen ${ }^{10}$, dan blijken er enige verschuivingen te bestaan.

Uit Figuur 7 blijkt dat de gemiddelde voorkeur voor 'natuurlijke' kenmerken in 2016 lager ligt dan in 2006. Vooral de voorkeur voor bossen is in de loop der jaren afgenomen, maar het blijft het meest favoriete landschapstype.

\footnotetext{
${ }^{10}$ Door de mens gemaakt.
} 


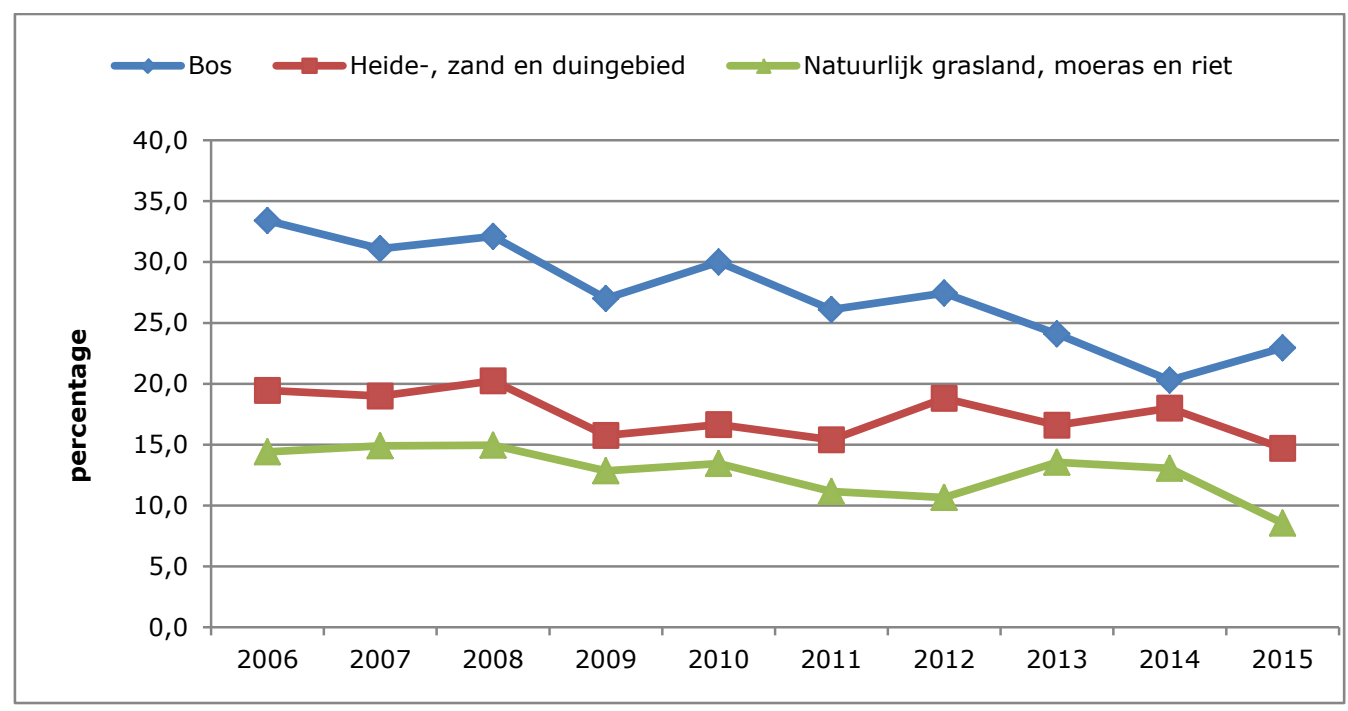

Figuur $7 \quad$ Verandering in voorkeuren (\%) bij natuurlijke kenmerken per jaar voor Zuid-Holland.

$\mathrm{Er}$ is een significante relatie tussen leeftijd en voorkeur voor bossen. Hoe ouder men is, hoe meer bos men wenst. En hoe jonger men is, hoe minder bos men wenst. Uit Tabel 3 komt naar voren dat de gemiddelde leeftijd lager geworden is de laatste jaren. Wellicht dat dit een verklaring kan zijn voor de afname in voorkeur voor bos. Ook voor heide-, zand- en duingebieden en voor natuurlijk grasland, moeras en rietvelden gelden dezelfde relaties met leeftijd. Bij deze twee type landschappen gaat de afname echter niet zo snel als bij bos. Aan de andere kant is er ook een significante relatie tussen geslacht en voorkeur voor bossen en natuurlijk grasland, moeras en rietvelden. Mannen hebben hier meer een voorkeur voor dan vrouwen. In het databestand zijn mannen oververtegenwoordigd. De voorkeur voor kleinschalig agrarisch landschap laat, na een stijging tot 2008, een daling zien. Ditzelfde zien we voor het open agrarisch gebied, hoewel daar de laatste jaren weer een kleine opleving valt te bespeuren in de voorkeuren. Zuid-Hollanders zijn het meest gecharmeerd van een halfopen agrarisch gebied. De laatste jaren zijn er wat schommelingen, maar de voorkeur blijft gemiddeld redelijk constant. Ook nu is er een significante relatie tussen deze drie landschapstypen met de leeftijd. En ook hier is de relatie positief, dat wil zeggen hoe ouder men is, hoe meer voorkeur voor het landschapstype. Mannen hebben significant meer voorkeur voor kleinschalig en open agrarisch landschap dan vrouwen.

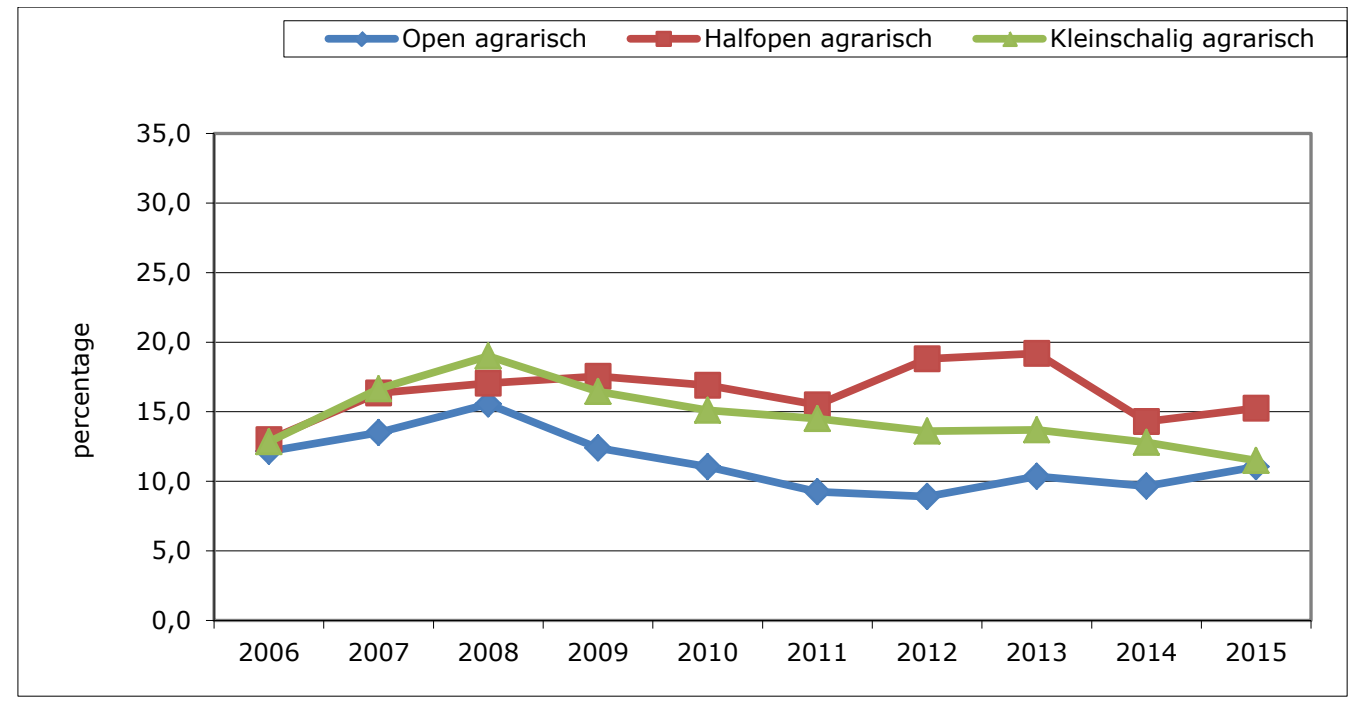

Figuur $8 \quad$ Verandering in voorkeuren (\%) bij agrarische gebieden per jaar voor Zuid-Holland. 
De voorkeur voor zee en grote meren en rivieren, kanalen en plassen laten een wisselend verloop zien. Zee en grote meren hebben een duidelijke voorkeur de laatste jaren, ook al neemt dat enigszins af. Dit geldt ook, maar dan in mindere mate, voor rivieren, kanalen en plassen. Er is alleen een significante relatie gevonden tussen rivieren, kanalen en plassen en leeftijd. Hoe ouder men is, hoe groter de voorkeur. Vrouwen hebben significant meer voorkeur voor deze watertypen dan mannen.

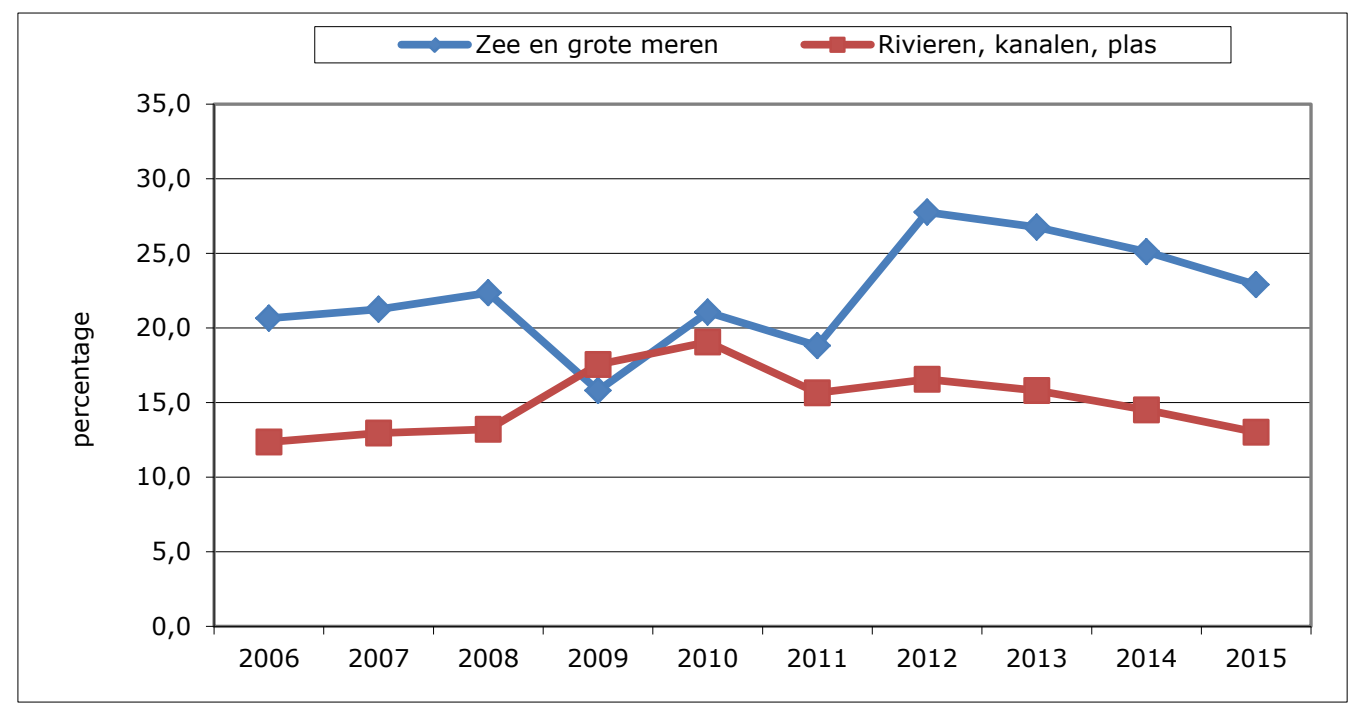

Figuur 9 Verandering in voorkeuren (\%) bij watertypen per jaar voor Zuid-Holland.

De voorkeuren voor meer antropogene kenmerken laten een vrij stabiel patroon zien gedurende de laatste jaren (Figuur 10). Bedrijfsterreinen en industriegebieden blijven het minst populair. Vooral vanaf 2013 is een dalende tendens te zien. Er bestaat een negatieve significante relatie tussen bebouwing en leeftijd. Is men ouder, dan is er minder voorkeur voor bebouwing. Vrouwen zijn significant meer gecharmeerd van bebouwing dan mannen.



Figuur 10 Verandering in voorkeuren (\%) bij antropogene kenmerken per jaar voor Zuid-Holland.

Bij de aanvullende kenmerken zijn ook enkele veranderingen te constateren in de loop der jaren. Figuur 11 geeft aan hoeveel men wil hebben van beide kenmerken in het ideale landschap. Een " 0 " staat voor "niets" en een "100" voor "heel veel". Uit Figuur 11 blijkt dat de voorkeur voor bezienswaardigheden stabiel tot licht gestegen is in de afgelopen jaren. De voorkeur voor 
hoogteverschillen neemt het laatste jaar weer af na een periode van een lichte toename. Jongeren ${ }^{11}$ vinden significant bezienswaardigheden en hoogteverschillen leuker dan ouderen. Mannen hebben significant meer een voorkeur voor hoogteverschillen dan vrouwen, die juist significant meer een voorkeur hebben voor bezienswaardigheden.

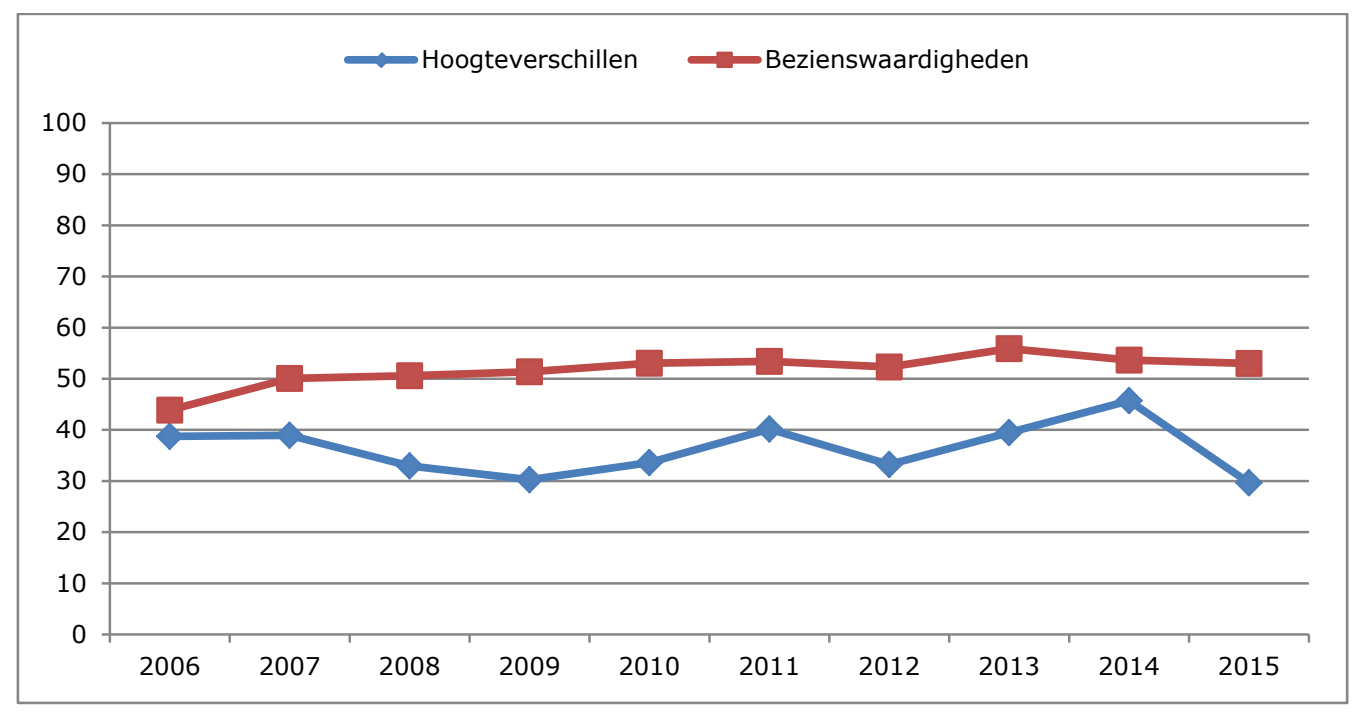

Figuur 11 Verandering in voorkeuren (\%) bij aanvullende kenmerken per jaar ( $0=$ geen; $100=z 0$ veel mogelijk) voor Zuid-Holland.

Bij Figuur 12 staat een "0" voor "geheel niet storend" en een "100" voor "zeer storend". Bij de storende kenmerken is een patroon te ontdekken dat de respondenten zich tot 2009 steeds minder aan storen, maar daarna een wisselend patroon laten zien (Figuur 12). Opvallend is dat het verloop bij alle drie de kenmerken hetzelfde is. Het niveau van "storen aan" is in 2015 echter wel lager dan in 2006. Dit geldt voor alle drie de kenmerken. Misschien is men er meer aan gaan wennen of is er een soort gelatenheid dat deze kenmerken gewoon onderdeel van het landschap zijn geworden. Er is geen significante relatie gevonden met leeftijd. Wel storen vrouwen zich significant meer dan mannen aan geluidbelasting en horizonvervuiling.

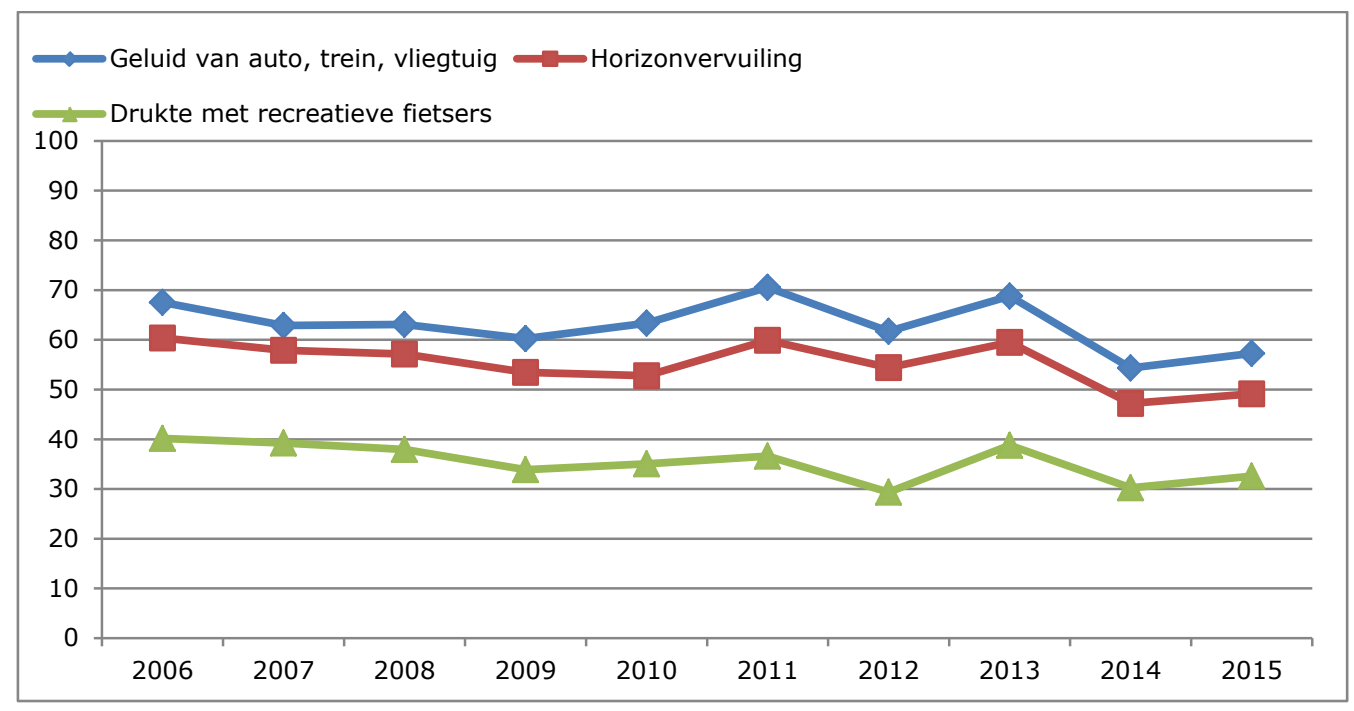

Figuur 12 Verandering in voorkeuren (\%) bij storende kenmerken per jaar ( $0=$ geheel niet storend; $100=$ zeer storend) voor Zuid-Holland.

${ }^{11}$ De toename van jongeren de laatste jaren (zie Figuur 3) in het databestand is wellicht een gevolg van de Quest-lezers die myplacetobe hebben bezocht. De gegevens bij deze analyse zijn uitsluitend gebaseerd op bezoekers van daarmoetikzijn. 


\section{$5 \quad$ Conclusies en aanbevelingen}

\section{$5.1 \quad$ Conclusies}

Met behulp van de websites www.daarmoetikzijn.nl en www.myplacetobe.eu is het goed mogelijk een beeld te krijgen in hoeverre Zuid-Hollanders het landschap in hun directe woonomgeving aantrekkelijkheid vinden. Belangrijk voor de interpretatie van de resultaten is het gegeven dat jongeren en ouderen ondervertegenwoordigd zijn en mannen oververtegenwoordigd. De website daarmoetikzijn is een hulpmiddel om inzicht te krijgen in de waardering van de kwaliteit van het landschap en hoe deze kwaliteit verbeterd kan worden. Vooral omdat de ruimtelijke spreiding van de deelnemers aan de websites overeenkomt met de daadwerkelijke spreiding van de burgers van ZuidHolland.

De antwoorden op de onderzoeksvragen zijn als volgt.

\section{Wat is het gemiddelde rapportcijfer dat Zuid-Hollandse burgers geven aan de aantrekkelijkheid van het landschap in hun directe woonomgeving en is dat rapportcijfer veranderd in de afgelopen tien jaar?}

Het gemiddelde rapportcijfer voor het landschap in de directe woonomgeving is de afgelopen jaren in Zuid-Holland een 6; een gemiddelde dat lager ligt dan in de rest van Nederland, dat een 6,9 scoort. Bovendien neemt het gemiddelde de laatste jaren af, met zelfs gemiddeld een onvoldoende vanaf 2011.

\section{Welke verklaringen zijn daarvoor te geven?}

Verantwoordelijk hiervoor lijken die landschapskenmerken te zijn die vooral een negatieve bijdrage leveren aan dat rapportcijfer. Vooral bebouwing drukt negatief op het rapportcijfer, maar ook bedrijventerreinen en industriegebieden en geluid van auto's, treinen en vliegverkeer, evenals bossen. Heide-, zand- en duingebieden leveren daarentegen een positieve bijdrage aan het rapportcijfer, evenals hoogteverschillen. Wel moet worden opgemerkt dat deze zes van de vijftien gebruikte indicatoren voor maar $8 \%$ bijdragen aan de verklaring van het rapportcijfer. Er zijn dus ook andere kenmerken die invloed hebben op de aantrekkelijkheidsscore.

\section{Zijn de verschillen in aantrekkelijkheid afhankelijk van waar men woont?}

Circa een derde van de bezoekers (32\%) uit Zuid-Holland geeft een onvoldoende (lager dan 6) aan het landschap rond de eigen woonplaats. Wanneer naar de ruimtelijke verdeling van gebieden met een onvoldoende voor de aantrekkelijkheid wordt gekeken, blijken deze geconcentreerd in een strook te liggen in gebieden met veel bebouwing, bedrijventerreinen, industriegebieden, horizonvervuiling en geluidbelasting. Dit zijn ook de gebieden waar relatief veel bezoekers wonen. Deze bezoekers hebben dus een stevige invloed op het gemiddelde aantrekkelijkheidscijfer van de hele provincie. Ruimtelijk gezien krijgt echter het grootste deel (80\%) van het landschap in Zuid-Holland een voldoende.

Is er een verschil in samenstelling en hoeveelheid van het landschap waar de burgers wonen en hun wensen over een ideaal landschap?

Bezoekers die in een gebied wonen met veel (half)open agrarisch gebied, hebben daar ook een voorkeur voor in hun ideale landschap. Dit geldt ook voor heide-, zand- en duingebieden en de zee en grote meren. Opvallend is dat dit ook geldt voor bebouwing en bedrijventerreinen en industriegebieden. Misschien speelt de relatie met werkgelegenheid hier een rol. Hoe meer horizonvervuiling in de woonomgeving van de bezoeker aanwezig is, hoe minder horizonvervuiling hij/zij in het ideale landschap wil zien.

Welke type landschap wordt als aantrekkelijk ervaren? Welke kenmerken zijn bepalend? De gemiddelde Zuid-Hollander wil het liefst $31 \%$ bos hebben in zijn/haar ideale landschap. Maar ook de zee en meren moeten aanwezig zijn (circa 21\%). Het ideale landschap moet verder 18\% heide-, 
zand- of duingebied hebben. Ook sloten, beken, rivieren en plassen en natuurlijk grasland, moeras en riet moeten voor $14 \%$ onderdeel uitmaken van het ideale landschap. De gewenste hoeveelheid halfopen agrarisch gebied is bijna even groot (16\%) als de gewenste hoeveelheid kleinschalig agrarisch gebied. Een voorkeur voor open agrarisch gebied (13\%), bebouwing (13\%) en industriegebieden (5\%) scoort gemiddeld laag.

Ruim de helft van de websitebezoekers wil enige mate van reliëf en twee derde wil bezienswaardigheden hebben in het ideale plaatje. $76 \%$ van de websitebezoekers in Zuid-Holland vindt het in enige mate storend om geluid te horen van auto's, treinen en/of vliegtuigen. Ook horizonvervuiling in de vorm van hoogbouw, windturbines en elektriciteitsmasten wordt door $70 \%$ als enige mate van storend gevonden. Drukte van recreatieve fietsers is relatief het minst storend. Iets meer dan de helft (57\%) vindt het enige mate van storend.

Opvallend zijn de analyses voor bos. Het is het landschapstype dat de grootste voorkeur heeft onder de Zuid-Hollanders. Die voorkeur neemt echter de afgelopen jaren wel af en bos levert zelfs een negatieve bijdrage aan de aantrekkelijkheidsscore. Hoe meer bos, hoe minder aantrekkelijk en hoe minder bos hoe aantrekkelijker het landschap wordt gevonden. Dat is in tegenspraak met veel ander landschapsonderzoek waar bossen zeer gewild zijn (Goossen et al., 2011; Direct Research, 2016). Het is nog onduidelijk welke rol dit landschapstype heeft. Misschien vinden de Zuid-Hollanders het bestaande bos niet aantrekkelijk. Misschien is er een relatie met bebouwing, waar wijken met (meestal) luxe woningen in het bos staan. Dit privébezit kan vervolgens weer van invloed zijn op de toegankelijkheid van het bos, dat dan weer doorwerkt in de aantrekkelijkheidsscore. En misschien is er een verband tussen stedelingen en niet-stedelingen betreffende voorkeur voor bos, ofwel tussen gebruiker en bewoners. Misschien is er een relatie tussen (half)open agrarisch gebied en bos, waar bewoners die in deze gebieden wonen juist geen bossen willen. Een vervolgonderzoek naar de rol van bos kan hier misschien duidelijkheid scheppen. Een mogelijkheid is om gebruik te maken van 1.450 emailadressen van Zuid-Hollanders die hebben aangegeven bereid te zijn om mee te doen met vervolgonderzoek.

Opvallend is ook de rol van sloten, beken, rivieren en plassen. In het ideale landschap is dit water gewild, maar dat komt niet tot uiting in de aantrekkelijkheidsscores van Zuid-Holland. Misschien ligt dit aan de visuele verschijning van dit type water. Zuid-Holland beschikt namelijk over relatief veel kaarsrechte sloten die een niet erg natuurlijke uitstraling hebben. Meestal zijn deze sloten gekoppeld aan een open agrarisch gebied dat niet de voorkeur heeft van de Zuid-Hollanders in hun samenstelling van ideale landschap. Ook hier zal nader onderzoek nodig zijn om de rol van dit type water te onderzoek voor de Zuid-Hollandse situatie.

\subsection{Aanbevelingen}

De provincie Zuid-Holland staat voor een grote opgave om het landschap aantrekkelijk te maken. De energie zal niet zozeer in het ontwikkelen van een bepaald landschapstype gaan zitten, maar meer in het tegengaan of het verbergen van ontwikkelingen die negatief bijdragen aan de aantrekkelijkheid. De provincie staat ook voor een grote bouwopgave. Juist bebouwing drukt negatief door op de aantrekkelijkheid. Aan een bouwopgave zou dus ook een groenopgave gekoppeld moeten worden. Waar gebouwd wordt, moet ook groen ontwikkeld worden en dan het liefst in de vorm van bos en natuurlijk grasland ${ }^{12}$. Het "verbergen" van de bedrijventerreinen en industriegebieden met een zeer brede groenzone zou het landschap visueel aantrekkelijker kunnen maken. Dit geldt ook voor de glastuinbouwgebieden en langs snelwegen. Opgaande begroeiing langs de snelwegen levert tevens een positieve bijdrage aan het tegengaan van geluidbelasting en fijnstof. Dwars door bouwlocatie, bedrijventerreinen en industriegebieden zou ook een brede groenzone ontwikkeld kunnen worden om de verbinding met de "oude" woongebieden te waarborgen.

\footnotetext{
${ }^{12}$ Uit de analyse komt eigenlijk een voorkeur voor heide-, zand- en duingebieden naar voren, maar het ontwikkelen van dit type is zeer plaatsgebonden en afhankelijk van de grondsoort en kan dus niet overal.
} 
Of een groot bosgebied, zoals een behoorlijke uitbreiding van het bestaande Bentwoud, gewenst is, is op basis van deze resultaten nog niet te zeggen. Daarvoor zijn de resultaten te tegenstrijdig. Er is een duidelijke voorkeur dat bossen een derde van een landschap van $25 \mathrm{~km}^{2}$ moeten beslaan, maar tegelijkertijd lijkt bos een negatieve bijdrage te leveren aan de aantrekkelijkheid. Nader onderzoek is hierover gewenst. 


\section{Literatuur}

Crommentuijn, L.E.M. J.M.J. Farjon, C. den Dekker, N. van der Wulp, 2006. Belevingswaardenmonitor Nota Ruimte 2006. Nulmeting landschap en groen in en om de stad. Milieu- en Natuurplanbureau, Bilthoven. MNP-publicatienummer 500073001

Goossen, C.M, M. Sijtsma, H. Meeuwsen en J. Franke, 2011. Vijf jaar daarmoetikzijn; Het ideale landschap volgens de Nederlanders op basis van analyse van de website www.daarmoetikzijn.nl Wageningen, Alterra-rapport 2197.

Direct Research, 2016. Publiekspeiling natuur. Amsterdam 
Wageningen Environmental Research Postbus 47

6700 AA Wageningen

T 0317480700

www.wur.nl/environmental-research

Wageningen Environmental Research

Rapport 2781

ISSN 1566-7197
De missie van Wageningen University \& Research is 'To explore the potential of nature to improve the quality of life'. Binnen Wageningen University \& Research bundelen Wageningen University en gespecialiseerde onderzoeksinstituten van Stichting Wageningen Research hun krachten om bij te dragen aan de oplossing van belangrijke vragen in het domein van gezonde voeding en leefomgeving. Met ongeveer 30 vestigingen, 5.000 medewerkers en 10.000 studenten behoort Wageningen University \& Research wereldwijd tot de aansprekende kennisinstellingen binnen haar domein. De integrale benadering van de vraagstukken en de samenwerking tussen verschillende disciplines vormen het hart van de unieke Wageningen aanpak. 



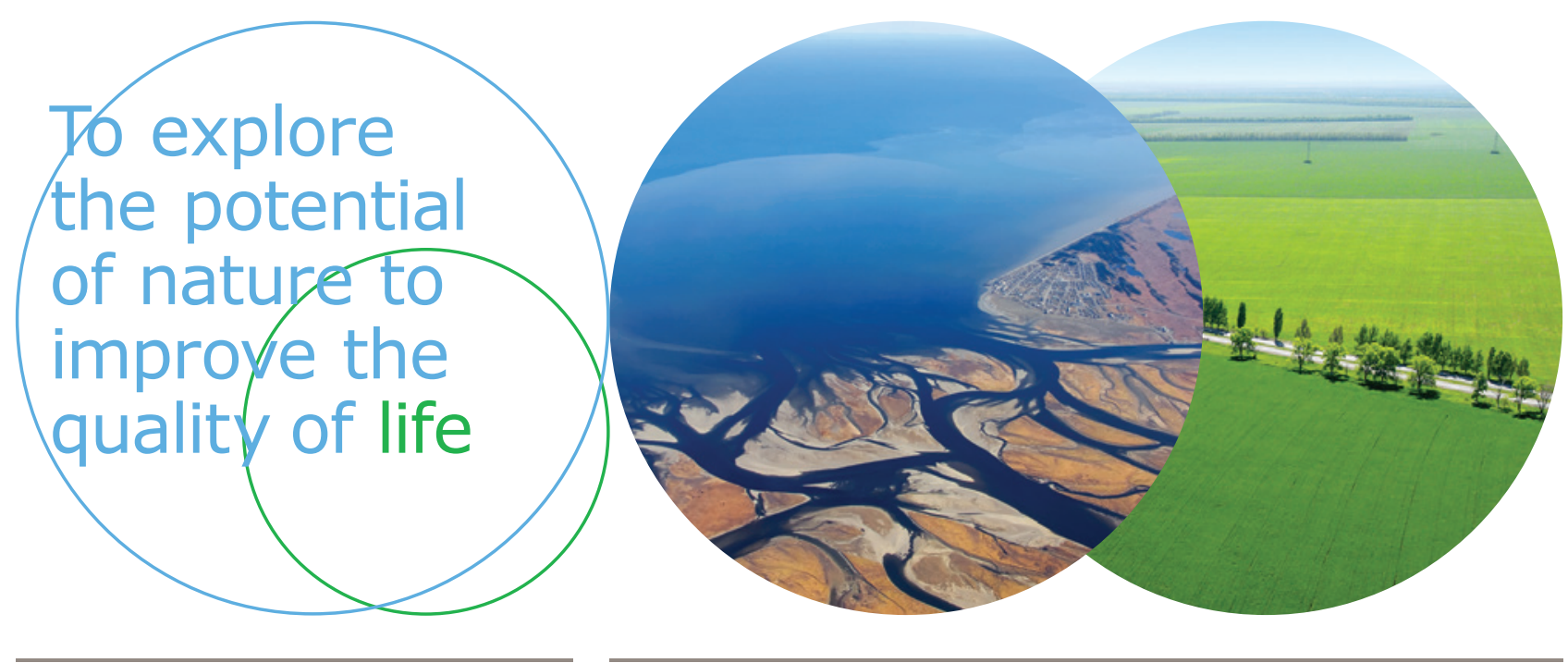

Wageningen Environmental Research Postbus 47

$6700 \mathrm{AB}$ Wageningen

T 317480700

www.wur.nl/environmental-research

Rapport 2781

ISSN 1566-7197
De missie van Wageningen University \& Research is 'To explore the potential of nature to improve the quality of life'. Binnen Wageningen University \& Research bundelen Wageningen University en gespecialiseerde onderzoeksinstituten van Stichting Wageningen Research hun krachten om bij te dragen aan de oplossing van belangrijke vragen in het domein van gezonde voeding en leefomgeving. Met ongeveer 30 vestigingen, 5.000 medewerkers en 10.000 studenten behoort Wageningen University \& Research wereldwijd tot de aansprekende kennisinstellingen binnen haar domein. De integrale benadering van de vraagstukken en de samenwerking tussen verschillende disciplines vormen het hart van de unieke Wageningen aanpak. 